\title{
WOŁOSI NA WĘGRZECH
}

\author{
RYSZARD GRZESIK
}

Abstract. The Wallachians in Hungary.

The article describes the presence of the Wallachians in the Hungarian Kingdom on the basis of sources from the earliest mentions on this population until the early modern period. In the Gesta Hungarorum the Wallachians were described as pastores Romanorum, the former inhabitants (together with the Slavs) of the region between the Great Hungarian Plain and the western part of Transylvania, conquered by Hungarian newcomers. In the description of the Eastern Europe (1308) Wallachians were identified with the pastors of the Romans. According to Simon of Kéza they transferred the knowledge of writing to the Szeklers. From the point of view of the Renaissance Italian and Hungarian humanists, they were the descendants of former Roman soldiers from the Dacia Traiana province. In the Hungarian documents, the Wallachian settlement in Transylvania is confirmed for the beginning of the $13^{\text {th }}$ century, however, the majority of information about them derived from the end of this period. The Wallachian presence was observed in the southern parts of Carpathians and western Transylvanian mountain ranges. Their migrations were reported in the Eastern and Western Carpathians, the main direction ran from Máramaros (Maramureş) (1320) towards Kysuce-Zvolen (Zolyom) region in the $16^{\text {th }}$ century and the border with Moravia. At first, migrated the East Romance population with the great (or dominant) contribution of the Slavic (probably Bulgarian) element. In the sources on Máramaros from the end of $14^{\text {th }}$ century the Wallachian settlers were identified with the Ruthenians. By contrast, west of Spiš (Zips, Szepes) the Slovaks and the Poles were called the Wallachians. There can be also the evolution of character of the Wallachian settlement observed. First, it had primarily ethnic attributes. Later, it came in specific socio-economic forms, connected with the colonization of the population (mainly the Slavs), primarily in the mountains. Some representatives of the Wallachian population (kenezii, vojevodae) were ennobled and became the part of the Natio Hungarica. They accepted the Catolicism and Hungarian identity. The rest of the population preserved the Orthodox faith and was subjugated. The Wallachians dealt not only with the transhumant economy, but also the agriculture. Moreover, they were the soldiers (guards) on the borders or communication routes.

STRESZCZENIE. Artykuł opisuje obecność Wołochów w Królestwie Węgier od najwcześniejszych wzmianek o tej ludności do czasów wczesnonowożytnych. Rozpoczyna się od opisu informacji z Gesta Hungarorum, gdzie Wołosi zostali przedstawieni jako pastores Romanorum. Byli to dawni mieszkańcy (wraz ze Słowianami) pogranicza między Wielką Niziną Węgierską a zachodnim Siedmiogrodem, podbici przez węgierskich przybyszów. Szymon z Kézy sądził, że to rzymscy pasterze, którzy nauczyli Szeklerów pisma. Z pasterzami Rzymian utożsamiano ich w opisie Europy Wschodniej z 1308 roku. Renesansowi humaniści włoscy i węgierscy uważali, że Wołosi byli potomkami dawnych żołnierzy rzymskich z prowincji Dacia Traiana. Wzmianki o osadnictwie wołoskim w Siedmiogrodzie pochodzą z początku XIII wieku, ale najwięcej informacji na ten temat jest z końca tego stulecia. Obecność Wołochów obserwowano w Karpatach Południowych i górach zachodniego Siedmiogrodu. Odnotowano ich migracje w Karpatach Wschodnich i Zachodnich. Osadnictwo dotarło w XVI wieku z Marmaroszu (Máramaros/Maramureş) (1320) do regionu Koszyc i Zwolenia (Zolyom) oraz granicy z Morawami. Początkowo Wołosi byli wschodnio-romańską grupą ludności z dużym (być może dominującym) udziałem elementu słowiańskiego (być może bułgarskiego). W dokumentach o Marmaroszu z końca XIV wieku mowa zarówno o Wołochach, jak i Rusinach. Z kolei na zachód od Spisza (Zips, Szepes) pod nazwą Wołosi kryli się Słowacy i Polacy. Charakter osadnictwa wołoskiego ewoluował od cech etnicznych do rozwiązań społeczno-gospodarczych, przeważnie opartych na pasterstwie i kolonizacji ludności (głównie Słowian). Niektórzy przedstawiciele tej ludności (kenezii, vojevodae) zostali nobilitowani i stali się częścią Natio Hungarica. Zaakceptowali wiarę rzymskokatolicką i węgierską tożsamość. Pozostała ludność zachowała wiarę prawosławną a jej status ludności obniżył się do poziomu ludności zależnej. Wołosi zajmowali się pasterstwem, a później rolnictwem górskim i byli także strażnikami na trasach komunikacyjnych i granicach. 
Keywords: The Wallachians, Medieval and Pre-Modern Hungary, Transylvania, Slovakia, The Slavs, settlement, source-critism

Słowa kluczowe: Wołosi, Węgry średniowieczne i wczesnonowożytne; Siedmiogród; Słowianie, osadnictwo, źródłoznawstwo

Autor: Ryszard Grzesik, Instytut Slawistyki PAN, ul. Bartoszewicza 1B/17, 00-337 Warszawa; grzesik@man.poznan.pl, ORCID iD: https://orcid.org/0000-0001-7887-6895

Balcanica Posnaniensia. Acta et studia, XXVIII/1, Poznań 2021, Wydawnictwo Wydziału Historii UAM, pp. 93-131

ISBN 978-83-66355-68-2, ISSN 0239-4278. Polish text with summaries in English and Polish

doi.org/10.14746/bp.2021.28.5

\section{WOŁOSI W ŹRÓDŁACH NARRACYJNYCH, TRADYCJI HISTORIOGRAFICZNEJ I MITOLOGII NARODOWEJ*}

Wołosi w południowo-wschodniéj części kraju osiedleni, dumni są, że pochodzą wprost od Rzymian; ich mowa oczewiście [!] jest pochodzenia rzymskiego, jest to nadzwyczajnie zepsuta łacina, o któréj wolno wątpić, czyby z powodu mięszaniny innych jakichś odmian końcówek i obcych wyrazów przez Cycerona za rzymską uznaną być mogła, aczkolwiek Wołosi sami przezywają się Rumunami czyli Rumanami. Dzielą ich na dwie linie: Unguranów i Zingarów czyli Macedo-Wołochów (trudniących się po miastach li handlem tylko); wszyscy zaś razem stanowią lud jakiś mięszany, na którym piętno właściwego szczepu zupełnie zatartem zostało. Ich kraina jest punktem przejścia z Niemiec do Turcyi, z Węgier do Siedmiogrodu, z Rossyi do Austryi, z Turcyi do Polski. Uwagi godnem jest, że powierzchowność tego ludu nie wyrobiła się przyjemniejszą dla oka, jak to zwykle bywa u krzyżujących się ras, ale owszem zbrzydniała; słabowity żółty kolor każe się domyśleć niezdrowego klimatu, i tak jest rzeczywiście; ich kraj jest daleko górzystszym aniżeli węgierski nad Dunajem i Cisą. Słaby porost ich włosów dowodzi braku sił fizycznych, przy czem z powodu częstszych amalgamacyj ich z innemi szczepami, nierzadko napotykać się dają cienkie bląd włosy obok kruczych brwi i brunatnego koloru twarzy, czego za ozdobę bynajmniéj poczytywać nie można; ich budowa ciała jest oczewiście słabowita, ich wzrost niski; jednak nadzwyczajnie są raźni kiedy idzie o zabawę, bynajmniéj zaś o pracę, dla tego też ich domy podobniejsze są do mieszkań Troglodytów aniżeli do mieszkań ludzi ucywilizowanych. Są to po większéj części zapadłe budynki, często w całem znaczeniu wyrazu same jaskinie podziemne lub w części nad ziemię sterczące, na pochyłości góry, lekkim daszkiem z trzciny zaopatrzone, jakie w Indyach bywają ale jakie w Europie byćby już nie powinny. (...) Z pod tego ubrania na głowie wygląda pożądliwe i chytre oko; kobiety są nadzwyczajnie zmysłowe, namiętne, do zazdrości skłonne; męzczyzni [!], podejrzliwi, chytrzy, mściwi, wszyscy zaś okropnie leniwi. Ich żywność jest tak niegodziwa jak pomieszkanie: kukurydza stanowi główny ich pokarm, z niéj zwykli sobie gotować dość gęsty kléj; z niéj pieką sobie niesmaczny chleb lub placek, kołacz, którego gorącego jeszcze spożywają. (...) Po godzinie wyjmują z pod tego popiołu zwykle gorące, nie wypieczone, niestrawne ciasto, którego jednak Wołosi chciwie i z rozkoszą spożywają; do tego biorą surową kwaszoną kapustę lub słoninę, a bogaci obydwie razem, przy tem zwyczajny ich napój, nie bardzo miłym zapachem zalecająca się wódka z śliwek (śliwowica) swoję rolę odgrywa. Wieprzowina, ryby,

* Artykuł powstał w ramach projektu NPRH Wołosi w europejskiej i polskiej przestrzeni kulturowej. Migracje - osadnictwo - dziedzictwo kulturowe (Projekt nr 0604/NPRH3/H12/82/2014). 
a w porze letniéj wodniste melony, dalej czosnek, cebule, chrzan, hiszpański pieprz, są ich ulubionemi pokarmami, których również używają i Cyganie .

Ten obszerny opis Wołochów, ludności zamieszkującej południowo-wschodnią część Królestwa Węgierskiego, przedstawia ich jako zacofane społeczeństwo chłopskie żyjące w prymitywnych warunkach, rasę zdegradowaną fizycznie i moralnie przez życie w górach oraz złe odżywianie się. I to pomimo bardzo dostojnych korzeni, sięgających czasów rzymskich, choć ich język również uległ degradacji do tego stopnia, że Cyceron miałby problem z zakwalifikowaniem ich mowy do łaciny.

Taki był romantyczny obraz tego ludu, składającego się na mieszankę etniczną Węgier, w Polsce w połowie XIX w. ${ }^{2}$ Zadajmy sobie jednak pytanie o jego przeszłość w krainach wchodzących przez stulecia w skład państwa węgierskiego. Kiedy się właściwie pojawili, jak się rozprzestrzeniali, jaki tryb życia prowadzili. Nasze uwagi rozpoczniemy od przedstawienia obrazu Wołochów w kronikach węgierskich. Szczególnie skoncentrujemy się na ich genezie, która zainteresowała szczególnie humanistów i ich następców, dając początek pewnym przeświadczeniom żywym w nauce, ale i w powszechnej świadomości po dziś dzień. Kolejnym etapem rozważań stanie się próba nakreślenia przekazów dokumentarnych o Wołochach, punkt wyjścia do przyjrzenia się ich życiu społecznemu i stosunkom z resztą mieszkańców Królestwa i jego władzami.

Wołosi obecni są na kartach pierwszej zachowanej do naszych dni kroniki węgierskiej, anonimowych Gesta Hungarorum autorstwa mgra P., notariusza zmarłego już króla Béli. Dziś już nie ulega dla nas wątpliwości, że monarchą tym był Béla III, zmarły w 1196 r., a dzieło jego notariusza spisane zostało ok. 1200 r., a może koło 1210, a nawet po 1220, jak ostatnio próbuje się je datować. Przypomnijmy, że dzieło poświęcone jest przybyciu Węgrów do ich obecnej ojczyzny pod koniec IX w. Po raz pierwszy Wołosi pojawiają się w opowiadaniu książąt ruskich, którzy wyraźnie chcą skierować Węgrów na ziemie leżące za Karpatami i pozbyć się kłopotliwych gości.

Wodzowie ruscy zaś - aczkolwiek niechętnie - przystali na wszystkie warunki księcia Álmosa. Uprosili wszakże Álmosa, by opuścił ziemię halicką i udał się na zachód za Śnieżny Las do krainy panońskiej, należącej ongiś do króla Attyli. I zachwalali tę krainę jako nadzwyczaj żyzną. Mówili, że tamtędy przepływają słynne rzeki Dunaj i Cisa, a także inne rzeki obfitujące w wyborne ryby, że kraj ten zamieszkiwali Słowianie, Bułgarzy, Wołosi i pasterze rzymscy. Rzymianie ci, po śmierci króla Attyli nazywali krainę panońską pastwiskami dlatego, że ich trzody pasły się na panońskiej ziemi.

1 Opis jeograficzny i statystyczny Węgier, Siedmiogrodu, Kroacyi i Pogranicza Wojskowego, Warszawa 1849, s. 40-42.

2 Pogląd polskiej literatury romantycznej nt. Wołochów/Rumunów zanalizowała ostatnio Joanna Nowak, Piastuni dziejów. Wizerunki narodów europejskich w polskiej refleksji romantycznej, Warszawa 2018, https://ispan.waw.pl/ireteslaw/bitstream/handle/20.500.12528/603/J_Nowak_-_Piastuni_dziejow. pdf?sequence=1\&isAllowed=y [dostęp: 18.02.2020], s. 182-183 (Rumuni obok Madziarow i Słowian częścią Natio Hungarica, ale i podkreślenie nienawiści rozdzielającej poszczególne człony tego narodu), 277-279 (stosunek do księstw rumuńskich). 
Słusznie krainę panońską nazywano pastwiskami Rzymian, ponieważ wciąż Rzymianie pasą bydło na ziemi węgierskiej³.

Dowiadujemy się zatem o Panonii jako o ziemi z bogatymi pastwiskami przecinanej przez rzeki bogate w ryby. Kraina ta była nazywana pastwiskiem Rzymian, a zamieszkana jest obecnie (czyli w wyobrażonym przez Anonima IX w.) przez Słowian, Bułgarów, Wołochów oraz pasterzy Rzymian. To bogactwo ziemi, cenne z punktu widzenia pasterzy, jakimi Węgrzy byli w czasach przybycia do ojczyzny, ale i zapewne jeszcze w czasach Anonima, podkreślane jest w wielu miejscach tej, ale i w innych kronikach węgierskich ${ }^{4}$.

Wołochom poświęcony jest obszerniejszy ustęp w Gestach, obejmujący rozdziały 24-27. Opowiada się tu o walkach węgierskich najeźdźców przeciwko Gelou quidam Blacus, który władał terytorium zachodniego Siedmiogrodu. Pod jego rządami żyli Wołosi i Słowianie, którzy po śmierci Gelou w walce wybrali sobie na władcę węgierskiego wodza Tuhutuma (czyli Tétényego, używając współczesnego nazewnictwa). Stworzył on dynastię gyulów siedmiogrodzkich, z których wywodziła się Sarolta, matka św. Stefana. Mimo to Stefan pozbawił tronu Gyulę, gdyż ten nie chciał przyjąć chrześcijaństwa ${ }^{5}$. Wołosi pojawiają się również jako lud wspomagający księcia Banatu Glada obok Bułgarów i Kumanów6.

3 Anonimowego Notariusza króla Béli Gesta Hungarorum, tłum. A. Kulbicka, K. Pawłowski, G. Wodzinowska-Taklińska, wstęp i przypisy R. Grzesik, Kraków 2006 [dalej cyt. An. pol.], rozdz. 9, s. 57-59 z moją poprawką. Tekst łaciński ibidem, s. 56-58: Duces vero Ruthenorum, licet non sponte, tamen hec omnia Almo duci concesserunt, sed rogaverunt Almum ducem, ut dimissa terra Galicie ultra silvam Houos versus occidentem in terram Pannonie descenderent, que primo Athile regis terra fuisset, et laudabant eis terram Pannonie ultra modum esse bonam. Dicebant enim, quod ibi confluerent nobilissimi fontes aquarum, Danubius et Tyscia et alii nobilissimi fontes bonis piscibus habundantes, quam terram habitarent Sclaui, Bulgarii et Blachii ac pastores Romanorum. Quia post mortem Athile regis terram Pannonie Romani dicebant pascua esse eo, quod greges eorum in terra Pannonie pascebantur. Et iure terra Pannonie pascua Romanorum esse dicebatur, nam et modo Romani pascuntur de bonis Hungarie. Por. też wydanie łacińsko-angielskie: Anonymus and Master Roger. Anonymi Bele regis notarii Gesta Hungarorum. Anonymus, Notary of King Béla, The Deeds of the Hungarians, ed., transl. and annotated by M. Rady and L. Veszprémy. / Magistri Rogerii Epistola in miserabile Carmen super destructione regni Hungarie per Tartaros facta. Master Roger's Epistle to the Sorrowful Lament upon the Destruction of the Kingdom of Hungary by the Tatars, transl. and annotated by J. M. Bak and M. Rady, Budapest New York 2010 [dalej cyt.: An. ang.], s. 26-27. Tekst laciński w obu przywołanych edycjach oparty na: P. magistri, qui Anonymus dicitur, Gesta Hungarorum, ed. Ae. Jakubovich, D. Pais, [w:] Scriptores rerum Hungaricarum [dalej cyt.: SRH], t. 1, Budapestini 1937 [dalej cyt.: An. SRH], s. 45-46. Reprint z obszernym komentarzem w postscriptum opracowanym przez Kornéla Szováka i László Veszprémyego, Budapest 1997. Swoją drogą słowo pascuntur niekoniecznie oznacza wypas bydła, może to być wypas każdej zwierzyny. Por. Słownik łaciny średniowiecznej w Polsce, t. 7, z. 1 (52), Kraków 1992, szp. 140, gdzie podano przykład odnoszący się do owiec, http://scriptores.pl/elexicon/pl/lemma/PASCO\#sense_I, [dostęp: 20.10.2019]. Dla oszczędności miejsca pomijamy tu odesłania do wydania niemieckiego i słowackiego.

${ }^{4}$ Szersza analiza: R. Grzesik, The Valachian Way of Life in Stories about Domestic Origins in the Hungarian Medieval Chronicles, „Balcanica Posnaniensia” 2016, t. 23, s. 167-174.

${ }^{5}$ An. pol., rozdz. 24-27, s. 98-105; An. ang., rozdz. 24-27, s. 58-65; An. SRH, s. 65-69.

${ }^{6}$ An. pol., rozdz. 44, s. 142-149; An. ang., rozdz. 44, s. 92-99; An. SRH, s. 88-92. 
Jak widzimy, Wołosi, a właściwie Blachi ${ }^{7}$ są u Anonima wspomniani jako wrogowie Węgrów oraz mieszkańcy lokalnych organizmów politycznych, takich, jak państwo Gelou, który został przedstawiony jako władca wołoski. Ale obok nich pojawiali się tajemniczy pasterze rzymscy oraz sami Rzymianie jako dawni władcy tej krainy. Określenia Panonii jako pastwiska Rzymian, pascua Romanorum, pojawiało się zresztą i w innych kronikach węgierskich, a także w znającym dziejopisarską tradycję węgierską Opisie Europy z 1308 r. ${ }^{8}$, uznawane było też przez badaczy kronik za jeden $\mathrm{z}$ argumentów za tezą, że istniało praźródło kronik węgierskich, zaginione Gesta Ungarorum z XI lub początku XII w. Właściwie rzecz ujmując, była to kronika, która wciąż ulegała przeróbkom i zmianom dostosowującym jej tekst do bieżących koniunktur politycznych, przy czym dawne wersje ulegały zniszczeniu i zrekonstruować je możemy tylko badając niekonsekwencje przekazu późniejszych kronik 9 .

Problem tożsamości Wołochów i pasterzy rzymskich zanalizował nieżyjący już mediewista węgierski, Gyula Kristó. Zauważył on, że gdy Anonim pisał o Wołochach, miał rzeczywiście na myśli ten $\operatorname{lud}^{10}$. Co więcej, odzwierciedlenie w rzeczywistości miały też ludy skupione wokół Glada - wymienione oddają tytulaturę władców Drugiego Państwa Bułgarskiego rządzonego po 1185 r. przezAsenidów ${ }^{11}$. Prezentyzm, a zatem przenoszenie w przeszłość sytuacji znanej ze swojego osobistego doświadczenia i swojej epoki, był stałą przypadłością kronikarzy, nie dziwi zatem, że dla Anonima rzeczywistość znana z jego czasów była tożsama z rzeczywistością sprzed trzech stuleci. A zatem znani mu z zachodniego Siedmiogrodu Wołosi w jego opinii musieli tam przebywać już w czasach przybycia Węgrów.

Kim jednak byli pasterze Rzymian? Jak się wydaje, dla kronikarza oni również byli Wołochami, co podkreślił zresztą Bálint Hóman, badając zaginione Gesta ${ }^{12}$. Co więcej, to przeświadczenie spotykamy w już przywołanym Opisie Europy Środkowej, gdzie czytamy:

Notandum [est hic] quod inter machedoniam, achayam et thesalonicam est quidam populus ualde magnus et spaciosus qui uocantur blazi, qui et olim fuerunt romanorum pastores, ac in vngaria ubi erant pascua romanorum propter nimiam terre uiriditatem et fertilitatem olim morabantur. Sed tan-

${ }^{7}$ Gy. Kristó, Rómaiak és vlachok Nyesztornál és Anonymusnál, [w:] Idem., Tanulmányok az Árpád-korról, Bp. 1983, s. 170 wyjaśnia, że pod koniec okresu starowęgierskiego wargowo-zębowa spółgłoska $v$ była wymawiana jako bilabialna $\beta$, a w rezultacie jako frykatywna $b$.

8 Anonymi Descriptio Europae Orientalis „,Imperium Constantinopolitanum, Albania, Serbia, Bulgaria, Ruthenia, Ungaria, Polonia, Bohemia” anno MCCCVIII exarata, red. O. Górka, Cracoviae 1916, s. 44: Panoni autem, qui inhabitabant tunc panoniam, omnes erant pastores romanorum...

9 R. Grzesik, Kronika węgiersko-polska. Z dziejów polsko-węgierskich kontaktów kulturalnych w średniowieczu, Poznań 1999, s. 64-65; idem, Blasi and Pastores Romanorum in the Gesta Hungarorum by an Anonymous Notary, „Res Historica” 2016, t. 41, s. 25-34.

${ }^{10}$ Gy. Kristó, Rómaiak, s. 188.

11 Gy. Kristó, Rómaiak, s. 164-165.

12 B. Hóman, A Szent László-kori Gesta Ungarorum és a XII-XIII. századi leszármázói, Budapest 1925, rozdz. 6: A Szent László-kori Gesta és Anonymus. Korzystam w wersji internetowej: http://mek.niif. hu/07100/07139/html/0008/0008-338.html, [dostęp: 22.10.2019]. Inaczej Gy. Kristó, Rómaiak, s. 185186. 
dem ab ungaris inde expulsi, ad partes illas fugierunt; habundant enim caseis optimis, lacte et carnibus super omnes nationes ${ }^{13}$.

A zatem lud Blazi, czyli Wołosi, to potomkowie pasterzy rzymskich, którzy zostali wygnani przez Węgrów i znaleźli swe siedziby na pograniczu Achai, Macedonii i ziemi sołuńskiej słynąc ze swej dzielności i dzikości oraz ze wspaniałych wyrobów serowarskich, mlecznych i mięsnych. Wątpliwości co do identyfikacji obu ludów nie mieli też niektórzy badacze i wydawcy dzieła Anonima, próbując spójnik ac oddawać nie jako wyrażenie logicznej koniunkcji ('i'), lecz jako wyraz relacji wynikania ('to jest'). A zatem Blachii ac pastores Romanorum oznaczałoby: Wołosi, to jest pasterze Rzymian ${ }^{14}$. Lecz zwraca uwagę, że o Wołochach czytamy zawsze w kontekście Siedmiogrodu, natomiast pasterze Rzymian pojawiają się zawsze na zachód od Dunaju, w dawnej rzymskiej Panonii. Zatem, zdaniem Gyuli Kristó, pasterze Rzymian musieli mieć inną genezę, nawet jeśli utożsamieni zostali przez tradycję kronikarską z Wołochami.

Sprawę komplikuje jeszcze wiadomość Powieści lat minionych, wedle której Węgrzy przybyli do Panonii zastali w niej Wołochów i Słowian. Wołochów wygnali, a Słowian sobie podporządkowali ${ }^{15}$. Już Aleksiej Szachmatow zauważył, że przechowana jest tutaj zachodniosłowiańska tradycja pochodzenia wielkomorawskiego ${ }^{16}$. Za Martinem Homzą należałoby skorygować to spostrzeżenie rosyjskiego uczonego, szukając korzeni opowiadania bardziej na południe, wśród Słowian panońskich. To ich tradycja dostała się wraz z kulturowym dziedzictwem misji cyrylo-metodiańskiej do Bułgarii, a z niej na Ruśr ${ }^{17}$. Przyjęcie tej hipotezy pozwala nam dostrzec w Rzymianach Franków, groźnych sąsiadów państw słowiańskich w Panonii. Wiadomo, że imperium frankijskie obejmowało rozległe obszary Europy Zachodniej

13 Anonymi Descriptio, s. 12-13.

14 Jako pierwszy takie rozumienie zaproponował E. Gamillscheg, Blachii ac pastores Romanorum, [w:] Omagiu lui Ioan Lupaş la împlinirea vîrstei de 60 de ani, Bucureşti 1943, s. 270-276. Polemizuje $\mathrm{z}$ tymi próbami jako nieuprawnionymi z filologicznego punktu widzenia Dennis Deletant, Ethnos and Mythos in the History of Transylvania: the case of the chronicler Anonymus, [w:] Historians and the History of Transylvania, ed. by László Péter, New York 1992, s. 75. Por. Słownik łaciny średniowiecznej w Polsce, red. M. Plezia, t. 1: A-B, Wrocław-Warszawa-Kraków 1953-1958, szp. 895-896 s. v. Atque, acque, adque, ac, hac.

15 Повесть временных лет, ч. 1: Текст и перевод, wyd. Д. С. Лихачев, В. П. Адриановая-Перетц, Москва-Ленинград 1950, s. 21: Съдяху бо ту преже словъни, и волохове прияша землю словеньску. Посемъ же угри прогнаша вольхи, и насльдиша землю ту, и съдоша съ словъны, покоривше я подъ ся, и оттоле прозвася земля Угорьска.

16 Analiza: J. Leśny, Konstantyn i Metody apostołowie Słowian. Dzieło i jego losy, Poznań 1987, s. $82-101$.

17 M. Homza a kol., Svätopluk v európskom písomnictve. Štúdie z dejín svätoplukovskej legen$d y$, Bratislava 2013, s. 64. Mamy tu do czynienia z nurtem kulturowym dziedzictwa wielkomorawskiego (i panońskiego), por. R. Grzesik, Great Moravia as the Basis of the Central European Medieval Historical Tradition, [w:] Slovensko a Chorvátsko. Historické paralely a vzt'ahy (do roku 1780). Slovaćka i Hrvatska. Povijesne paralele i veze (do godine 1780.), red. M. Homza, J. Lukačka, N. Budak, Bratislava 2013, s. 66-71. 
z przewagą ludności germańskiej na wschodzie, a romańskiej (neołacińskiej) na zachodzie. A ludność romańska przez Słowian określana była przejętą od Germanów nazwą Włochów. Otwiera to klucz do zapiski o panońskich Wołochach ruskiego latopisu. Wydaje się, że Wołosi to Frankowie, którzy istotnie zostali pokonani i wygnani z Panonii przez Węgrów. Sądzę też, że tradycja słowiańskich Panończyków przetrwała najazd Węgrów i ich powolną madziaryzację, dostarczając materiału anonimowemu notariuszowi. W jego pasterzach Rzymian dostrzec można za Gyulą Kristó frankijskich duchownych, (re)chrystianizujących obszary Panonii z ramienia arcybiskupstwa salzburskiego i dających się mocno we znaki słowiańskim „owieczkom” choćby przez nakładanie dziesięcin. W Powieści lat minionych zapisano zatem tradycję o politycznych kontaktach słowiańsko-frankijskich, natomiast węgierski kronikarz bezwiednie przechował tradycję o stosunkach kościelnych. Bezwiednie, gdyż za bardzo już się nie orientował, o kogo chodzi i wiązał pasterzy z nowym ludem romańskim, istotnie parającym się pasterstwem ${ }^{18}$.

Pasterstwo nie było zresztą jedynym zajęciem Wołochów. Anonim wspomina, że ,w piaskach tych rzek ludzie zbierają złoto, a złoto tej ziemi (czyli zachodniego Siedmiogrodu) jest najlepsze; że kopie się tam sól i kamień panwiowy, a przy tym mieszkańcy tego terenu są najnędzniejsi ze wszystkich na świecie, gdyż są to Wołosi i Słowianie"19. Cytat ten pokazuje, że zdaniem kronikarza Wołochom nie było obce górnictwo metali szlachetnych oraz soli, z którego zresztą słynął Siedmiogród.

A jednak w XIII w. byli oni postrzegani przede wszystkim przez pryzmat pasterstwa, jak świadczą o tym skąpe uwagi Szymona z Kézy, który trzykrotnie wspomina ich w kontekście Historii Huńskiej. Byli to pasterze Rzymian, którzy po przybyciu Hunów do Panonii dobrowolnie w niej pozostali ${ }^{20}$. Najciekawsza dla nas jest chyba kolejna wzmianka Szymona o kontaktach wołosko-szeklerskich. Dowiadujemy się oto, że oba ludy spotkały się w górach mieszając się ze sobą, a Szeklerzy od Wołochów mieli przejąć pismo ${ }^{21}$. Wydaje się, że w tym przypadku kronikarz mógł widzieć sposób odhaczania policzonych owiec w stadzie za pomocą karbów i na tej podstawie uznał, że runy szeklerskie wywodzą się właśnie od znaków stosowanych przez Wołochów. Swoją drogą można dostrzec tu uznanie dla wołoskiej kultury, któ-

18 Gy. Kristó, Rómaiak, s. 160-161; R. Grzesik, Blasi and Pastores Romanorum, passim. A. Madgearu, The Romanians in the Anonymous Gesta Hungarorum. Truth and Fiction, Cluj-Napoca 2005, passim, odnotowując (s. 50-51) podaną w tekście możliwość skłania się jednak do przyjęcia możliwości o wczesnym napływie do Panonii ludności wschodnio-romańskiej (rumuńskiej) (s. 81-82), co wydaje mi się jednak mało prawdopodobne.

19 An. pol., rozdz. 25, s. 101; tekst łaciński s. 100: -- et quod in arenis eorum aurum colligerent et aurum terre illius optimum esset et ut ibi foderetur sal et salgenia et habitatores terre illius viliores homines essent tocius mundi, quia essent Blasii et Sclaui - -. W polskim przekładzie zamiast Wołochów użyto omyłkowo nazwy Bułgarów.

20 Simonis de Kéza Gesta Hungarorum. Simon of Kéza, The Deeds of the Hungarians, With a study by J. Szücs, wyd. L. Veszprémy i M. Rady, Budapest 1999 [dalej cyt.: Kézai], rozdz. 14, s. 54-55: Blackis, qui ipsorum [czyli dawnych mieszkańców] fuere pastores et coloni, remanentibus sponte in Pannonia.

${ }^{21}$ Kézai, rozdz. 21, s. 70-71: ... non tamen in plano Pannoniae, sed cum Blackis in montibus confinii sortem habuerunt, unde Blackis commixti literis ipsorum uti perhibentur. 
ra zdolna była zdaniem kronikarza do wytworzenia swojego pisma. Wreszcie trzecia i ostatnia wzmianka mistrza Szymona o interesującym nas ludzie głosi, że byli oni przybyszami w Panonii, sługami króla Attyli, którzy pozostali tam po wycofaniu się Hunów ${ }^{22}$.

Obraz Wołochów nie zmienia się w późnośredniowiecznych kronikach opartych na Kézańskiej Historii Hunów oraz przeróbkach tekstów kronikarskich i określanych zbiorczą nazwą Kompozycji kronikarskiej z XIVw. Tu jednak pojawia się nowy szczegół. Ponieważ opowiadanie kronik doprowadzone jest do czasów sobie współczesnych, czyli połowy XIV w., nagle Wołosi pojawiają się jako twórcy własnego państwa, które w dodatku skutecznie przeciwstawia się Węgrom i zadaje im klęskę, jak wojewoda Bazard Karolowi Robertowi ${ }^{23}$.

Zmianę w postrzeganiu Wołochów przynosi XV w. i prace humanistów włoskich, którzy dostrzegli w Europie Południowo-Wschodniej lud mówiący zepsutą łaciną i tworzący swoje państwo. Jednym z pierwszych był Eneasz Sylwiusz Piccolomini, późniejszy papież Pius II, jeden z najwybitniejszych intelektualistów na Piotrowym tronie. Na marginesie swojego opowiadania o tym ludzie wspomniał on, że wywodzili się od dawnych osadników rzymskich z epoki cesarza Trajana, a ich nazwa to zniekształcona nazwa legionu Flaccus, który wysłany został do obrony granic Imperium przed Sarmatami. Jednak potomkowie legionistów stali się większymi barbarzyńcami, niż sami barbarzyńcy ${ }^{24}$. Myśl jego rozwinął późniejszy o pół wieku humanista wło-

22 Kézai, rozdz. 23, s. 72-75: ... Sclavis tantummodo, Graecis, Teutonicis, Messianis et Vlachis advenis remanentibus in eadem, qui vivente Ethela populari servitio sibi serviebant. Wydawcy tekstu angielskiego w Mesjanach dostrzegają Morawian.

${ }^{23}$ Chronici Hungarici compositio saeculi XIV., red. A. Domanovszky, SRH, t. 1, rozdz. 14, s. 269, rozdz. 21, s. 279, rozdz. 23, s. 281, rozdz. 209, s. 496-500; nowe wydanie: Chronica de gestis Hungarorum e Codice Picto saec. XIV. Chronicle of the Deeds of the Hungarians from the Fourteenth-Century Illuminated Codex, red. J. M. Bak, L. Veszprémy, wstęp: N. Kersken, Budapest - New York 2018, s. 42, 56, 370-378; Johannes de Thurocz, Chronica Hungarorum, cz. 1: Textus, red. E. Galántai, J. Kristó, Budapest 1985, wg indeksu (głównie wydarzenia z XIV i XV w.).

24 Pii secundi pontificis maximi Commentarii rervm memorabilivm, quae temporibus svis contingervnt, a Reverendissimo Domine Ioanne Gobellino Vicario Bonnensi iamdiu composite et a Reverendissimo Patre Domine Francisco Bandino Picolomineo Archiepiscopo Senensi ex vetusto originali recogniti ... Prostat Francofurti in Officina Avbriana Anno 1614, https://books.google.pl/ books?redir_esc=y\&hl=pl\&id=CJQVBq5x6AQC\&q=Valachi\#v=snippet\&q=Valachi\&f=false [dostęp: 23.10.2019], s. 296: Valachi populi sunt vltra Danubium habitantes inter Euxinum mare, et regiones, quas hodie Transiluanas appellant; in quis septem ciuitates Theutonici sermonis existunt. Valachi lingua vtuntur Italica, verum imperfecta, et admodum corrupta sunt qui legiones Romanas eo missas olim censeant aduersus Dacos, qui eas terras incolebant legionibus Flaccum quondam praefuisse, à quo Flacci primum, deinde Valachi, mutatis litteris sint appellati, quorum posteri (vt ante relatum est) barbariores barbaris euasere. Na s. 325 czytamy, że Valachi corrupto Italico [loquuntur]. O ich genezie czytamy wyżej, na s. 222: Non imus inficias, multos ex Romanis barbaros, ac pariter ex barbaris Romanos fieri potuisse quemadmodum Valachos vltra Danubium cernimus, qui ex Italicis aduersus Sarmatas missi, vt fines imperii defenderent, ipsis barbariores euasere: quamuis verbis quibusdam nostratibus vrantur. Por. też Aenae Sylvii Piccolominei ... opera quae extant omnia... His quoque accessit Gnomologia..., Basileae [1551], https://archive.org/details/ARes63312/page/n3 [dostęp: 23.10.2019], s. 391 (żołnierze węgierscy nie znający węgierskiego), 393 (język tak przekształcony, że słabo zrozumiały przez Włochów). 
ski działający na dworze Macieja Korwina, Antonio Bonfini. Wołoszczyzna i Wołosi pojawiają się na karcie jego Dekad historii Węgier kilkakrotnie, np. utożsamia z nimi Kumanów, którzy pod koniec XI w. najechali Węgry, zna także dwa państwa wołoskie: Valachiam Transalpinam oraz Moldaviam. Najciekawsze jednak są jego rozważania nad pochodzeniem Wołochów i etymologią ich nazwy, w czym podąża za swym poprzednikiem ${ }^{25}$. Dla Antala Verancsicsa Wołosi to potomkowie Rzymian, którzy zasiedlili rozległe tereny Bałkanów oraz Siedmiogród, stworzyli też własne państwa. Oni sami określają się tą nazwą, natomiast określenie Wołochów jest obce, bo tak od Flawiuszy zwali ich Ilirowie, od których przejęli je Węgrzy, by nazwać tak pasterzy rzymskich. Ich język wywodzi się z łaciny ludowej ${ }^{26}$. Również Gáspár Heltai, autor pierwszej kroniki napisanej w języku węgierskim, nie miał wątpliwości, że w Siedmiogrodzie żyją rómaiak, bo tak nazywają się Wołosi żyjący w lasach i górach, którzy są potomkami Rzymian. Są to ludzie bogaci, pracujący w kopalniach szlachetnych metali i drogich kamieni. Na ich terytorium zachowały się inskrypcje zapisane w języku urzędowym, czyli rzymskim. Kraina obfituje w miasta, kronikarz wymienia też dużą wieś wołoską koło Ulpiany, dzisiejszą miejscowość Kőresbánya, gdzie również znajduje się szlachetne kamienie ${ }^{27}$.

Jak widzimy, dla autorów renesansowych, bądź to Włochów odkrywających Europę Środkową, bądź też poddanych monarchów węgierskich, Wołosi bez żadnych wątpliwości byli potomkami dawnych osadników rzymskich w Dacji, zdobytej dla imperium przez Trajana. Nazwę tłumaczono od legionu Flawiuszy, miała to być nazwa zniekształcona przez stulecia. Zwracano uwagę na ich język, który słusznie wiązano z łaciną, oraz na ich gospodarkę pasterską, ale również górnictwo.

Przeświadczenie o rzymskim rodowodzie Wołochów, znane również w Hospodarstwie Mołdawskim²8, przetrwało w Siedmiogrodzie do początków działalno-

25 Antonii Bonfinii Rervm Vngaricarvm Decades Qvatvor cvm dimidia, (...), ed. Ioannes Sambucus, Francofvrti, Apud Andream Wechelum 1581 Cum priuilegio decem annorum, https://books.google.hu/ books? $\mathrm{id}=8 \mathrm{sc} 9 \mathrm{AAAAcAAJ} \& \mathrm{printsec}=$ frontcover $\& \mathrm{hl}=\mathrm{pl} \mathrm{H}_{\mathrm{v}}=$ onepage $\& \mathrm{q} \& \mathrm{f}=$ false $[$ dostęp: 15.10.2019], Decas II, Liber VII, s. 277: Valachi enim è Romanis oriundi, quod eorum lingua adhuc fatetur, quum inter tam varias Barbarorum gentes sita, adhuc extirpari non potuerit, vlteriorem Istri plagam, quam Daci ac Getae quondam incoluere, habitarunt, nam citeriorem Bulgari, qui è Sarmatia prodiere, deinde occuparunt. E legionibus enim, \& coloniis, à Traiano, ac caeteris Romanorum Imperatoribus, in Daciam deductis, Valachi promanarunt. Quos Pius à Flacco, pronunciatione Germanica Vlachos dici voluit: nos contra, dictos esse censuimus, quum sagittandi arte praepolleant. Nonnulli Valachiae, à Diocletiani filia nomen inditum censuere, quae illorum Principi nupsisse fertur. Itaque hi Graecorum precibus exorati, Adrianopolim Latinorum obsidione liberarunt. Sed de his ista retulisse sat sit.

26 Verancsics Antal, M. Kir. helytartó, esztergomi érsek, Összes munkái, közli Szalay László, M. Akad. T., első kötet: Történelmi dolgozatok deák nyelen, Pest 1857, De rebus gestis Hungarorum ab inclinatione Regni, s. 1-337; rozdz. VII: Antonius Wrancius Sibenicensis Dalmata de situ Transsylvaniae, Moldaviae et Transalpinae, s. 119-151.

${ }^{27}$ Heltai Gáspár, Krónika az magyaroknak dolgairól, wyd. M. Kulcsár, wstęp P. Kulcsár, Békéscsaba 1981, VI. Rész Micsoda népek laktanak legyen az magyarok elött Erdélyországban?, s. 41-42.

28 Gdzie o rzymskim pochodzeniu mieszkańców Mołdawii przeświadczeni byli kronikarze Grigore Ureche (1590/95 - 1647/48) oraz Miron Costin (1633-1691); zob. E. Niederhauser, A történetírás története Kelet-Európában, Budapest 1995, s. 363-365. 
ści intelektualistów wywodzących się spośród Wołochów, lecz świadomych swego rzymskiego pochodzenia i określających się już jako Rumuni. Dążyli oni do uzyskania dla Rumunów statusu narodu równoprawnego trzem dotychczasowym narodom Siedmiogrodu: Węgrom, Szeklerom i Sasom. Ich działalność związana była z rekatolizacyjną działalnością Habsburgów, którzy doprowadzili do zawarcia unii kościelnej między duchowieństwem prawosławnym a rzymsko-katolickim. Powstały kościoły unickie, a ich duchowni pobierali nauki w seminariach i szkołach Monarchii. Przejęli oni przeświadczenie o rzymskim rodowodzie swoich rodaków. Stało się ono właściwie aksjomatem budującym rumuńską świadomość narodową i z biegiem czasu nabierającym coraz bardziej antywęgierskiej wymowy. Powstała historiografia tzw. szkoły siedmiogrodzkiej, którą reprezentowali Samuil Micu Klein, Gheorghe Şincai oraz Petru Maior. Byli oni duchownymi (z wyjątkiem Şincaia, który porzucił stan duchowny) i cenzorami w Drukarni Uniwersyteckiej w Budzie. Popierali oni druk książek po rumuńsku, zarówno w cyrylicy, jak i w nowo wprowadzonym do tego języka alfabecie łacińskim. Bardzo podkreślali rzymskie korzenie Rumunów i ich autochtonizm zarówno w Dacji, czyli Siedmiogrodzie, jak i na południe od Dunaju w Bułgarii. Idee te, początkowo obce dziejopisarstwu Wołoszczyzny, stopniowo przyjęły się w jednoczących się księstwach rumuńskich stając się wyrazem dążeń do zjednoczenia z Rumunami siedmiogrodzkimi, a po realizacji programu Romania Mare utrzymania jedności państwa. Zwolennikiem koncepcji dako-rzymskiej był zarówno przywódca Żelaznej Gwardii, jak i narodowo-komunistyczny szef ,socjalistycznej” Rumunii. Koncepcja ta do dziś jest obecna na salonach naukowych w Rumunii, mimo że poważni badacze podchodzą do niej sceptycznie jako raczej do obiektu badań nad dziejami świadomości społecznej niż hipotezy wyjaśniającej rzeczywistość historyczną w duchu Rankowskim ${ }^{29}$.

Analiza węgierskich i związanych z Węgrami źródeł narracyjnych pokazała, że Wołosi obecni są w nich od najdawniejszych czasów, przynajmniej od dzieła anonimowego notariusza króla Béli. Przypomnijmy, że wspomniał on o Wołochach Blachach, budujących swe państwo podbite następnie przez Węgrów w zachodnim Siedmiogrodzie, a także o pasterzach rzymskich. Na pasterski charakter gospodarki Węgier wskazują zresztą wszystkie źródła, które z Wołochami zaczęły utożsamiać pasterzy rzymskich, pojawiających się na zachód od Dunaju, a zatem w Transdanubii obejmującej tereny historycznej rzymskiej prowincji Panonii. Należy przychylić się do poglądu, że pierwotnie pasterze ci oznaczali frankijskich duszpasterzy, którzy mocno musieli dać się we znaki swoim słowiańskim „owieczkom”. Wydaje się zatem, że tradycja ta jest pozostałością świata wyobrażeń Słowian panońskich i jako taka wraz $\mathrm{z}$ tradycją wielkomorawską trafiła w końcu do latopisarstwa ruskiego. Jednak utożsamienie Wołochów i pasterzy pozostało w kronikach. Kolejnym elementem ewolucji wiedzy o Wołochach była działalność humanistów włoskich, którzy odkrywali w Europie Południowo-Wschodniej lud mówiący podobnym do nich językiem, ale stojący na niższym poziomie cywilizacyjnym. Wtedy pojawiła się próba ich powią-

${ }^{29}$ O rozwoju historiografii rumuńskiej zob. E. Niederhauser, A történetírás, s. 363-421. 
zania z popularną historią antyczną, czyli z zajęciem przez cesarza Trajana Dacji. Próbowano też powiązać nazwę Wołochów z legionem Flawiuszy, a także odkryto, że oni sami określają się jako Rumuni. Wątek ten rozwijany był przez następne dwa stulecia w Siedmiogrodzie i wykorzystany został przez intelektualistów rumuńskich do stworzenia mitu etnogenetycznego narodu rumuńskiego, który w końcu zaczął uzasadniać konieczność zjednoczenia trzech części zamieszkałych przez Rumunów w jedno państwo. Jego filarem jest przeświadczenie, że kolebką Rumunów jest Siedmiogród.

Tymczasem w miarę rozwoju historiografii krytycznej na warsztat badaczy zaczęły trafiać inne kategorie źródeł: dokumenty, potem wyniki badań nad językiem i onomastyką. I one wykazały, że obraz przekazany przez tradycję humanistyczną i nacjonalistyczną nie w pełni odpowiada prawdzie.

\section{OSADNICTWO WOŁOSKIE PO WEWNĘTRZNEJ STRONIE ŁUKU KARPAT}

Wiadomo ze źródeł bizantyńskich, że Wołosi wchodzili w skład armii Manuela I Komnena, która w 1166 r. najechała na Siedmiogród z nieoczekiwanej dla Węgrów strony - od wschodu. Zdaniem Alexandru Madgearu zasilili ją Wołosi żyjący w Dobrudży ${ }^{30}$. Najpóźniej wtedy zapoznali się z warunkami panującymi w Karpatach oraz górach zachodniego Siedmiogrodu. W źródłach dokumentowych pojawiają się późno. Pierwszym dokumentem, gdzie pojawia się określenie terra Blacorum (jako wyznacznik granicy nadania) jest podfałszowany przez Krzyżaków dokument nadania dla nich przez króla Andrzeja II ziemi Burza (Burzenland, Barcaság) z 1222 r. Mowa jest w nim, że z płacenia cła zwolnieni są ci, którzy transierint per terram Siculorum aut per terram Blacorum. Sugeruje to, że Ziemia Wołochów mieściła się gdzieś w Karpatach Południowych, na południe od linii Braszów - Sybin ${ }^{31}$. Lokalizację tę potwierdzałoby nadanie w 1223 r. dokonane przez Andrzeja II dla klasztoru cystersów w Kerc (Cârţa) położonym nad Alutą na zachód od miejscowości Fogaras (Făgăraş) exemptam de Blaccis ${ }^{32}$ oraz nadanie Sasom w 1224 r. silvam Blacorum et Bissenorum do wspólnego użytkowania ${ }^{33}$. W 1247 r. joannici otrzymali od króla Béli IV terram

30 Kurze Geschichte Siebenbürgens, red. B. Köpeczi, Budapest 1990, s. 186 (autorem tej części jest László Makkai); A. Madgearu, Vlach Military Units in the Byzantine Army, [w:] Самоиловата држава и Византија: историја, легенда, традиција, наследство. Зборник на трудови од Меѓнародниот симпозиум „Денови на Јустиниан I“, Скопје, 17-18 октомври 2014, red. М. Б. Панов, Скопје 2015, s. 52.

31 Documenta Historiam Valachorum in Hungaria illustrantia usque ad annum 1400 p. Christum, curante Emerico Lukinich, prof. ord. Universitatis Budapestinensis et adiuvante Ladislao Gáldi ediderunt Antonius Fekete Nagy et Ladislaus Makkai, Budapestini 1941, https://library.hungaricana.hu/hu/view/ KozMagyOkmanytarak_documenta_historiam_1941/?pg=8\&layout=s; [dostęp: 26.01.2020]; nr 1, s. 3; analiza dokumentu: W. Kętrzyński, $\bar{O}$ powołaniu Krzyżaków przez księcia Konrada, Rozprawy Akademii Umiejętności, Wydział Historyczno-Filozoficzny, t. 45, 1903, s. 130-145 i nadb., Kraków 1903, s. 6-21.

32 Documenta, nr 3, s. 9. O okolicznościach założenia klasztoru zob. Historia Scepusii. Dejiny Spiša, red. M. Homza, S. A. Sroka, t. 1, Bratislava-Kraków 2009, s. 256-257 (M. Homza).

33 Documenta, nr 4, s. 10-12. 
de Zeurino cum alpibus ad ipsam pertinentibus et aliis attinentiis omnibus, pariter cum kenazatibus Joannis et Farcasii usque ad fluvium Olth, excepta terra kenazatus Lytuoy woiauode quam Olatis relinquimus. Otrzymali również Kumanię excepta terra Szeneslai woiauode Olatorum, quam eisdem relinquimus - jest to pierwsza wzmianka o pobycie Wołochów w banacie Szörény (Severin) ${ }^{34}$. W 1283 r. w dokumencie Władysława Kumańskiego rozstrzygającego spory wewnątrz rodu Ratót wspomniano m.in. possessiones Wylak, Kuesd et Olahteluk vocatas in comitatu Byhoriense existen$t^{35}{ }^{35}$. Leżały one na wschód od Waradynu (Oradei) w okolicy miejscowości Tileagd Mezőtelegd na skraju Gór Biharskich. W 1292 r. Wołosi pojawiają się w nadaniu ziem w komitacie Hunyad (Hunedoara) nad Maruszą dla Aleksandra syna Gyürka z rodu Ákos ${ }^{36}$, rok później w komitacie Alsó-Fejér (Alba de Jos) ${ }^{37}$. W 1307 r. w dokumencie kapituły siedmiogrodzkiej opisującym jej granice w komitacie Hunyad i Fogaras pojawia się nazwa Újfalu, dzisiejsze Oláhújfalu - Noul Român koło klasztoru w Kercu ${ }^{38}$. W 1319 r. Wołosi wzmiankowani są w komitacie Krasso (Caraş) leżącym na zachód od banatu Szörény (Severin) i dochodzącym do Dunaju na wschód od Żelaznej Bramy ${ }^{39}$. W tym samym komitacie, w jego północno-wschodniej części, w 1337 r. odnotowano pierwszą bezsprzecznie rumuńską nazwę osobową: Caprewar, dzisiejszą Căprioarę ${ }^{40}$. W 1326 r. bezsprzecznie odnotowano nadanie przez króla Karola Roberta ziemi w Marmaroszu kniaziowi Stanisławowi na prawie szlacheckim, co jest pierwszą wzmianką o osadnictwie wołoskim w tym komitacie ${ }^{41}$. Jednak już w 1317 r. wystawiono dokument dla Dragomira, syna Dragosa w sprawie posiadłości Gyulafalva i Nyíres, o którym wzmianka zachowała się w Protocollum productionis nobilium, czyli materiałach komisji porządkującej w 1763 r. tytuły prawne do majątków szlacheckich w Marmaroszu ${ }^{42}$. Po 1319 zaczyna się też osadnictwo w położonej na północ od tego komitatu Ugocsy ${ }^{43}$. W 1324 r. odnotowano Olahteluke (Oláhtelke) w komitacie Bihar na północny wschód od miejscowości Telegd nad Kereszem ${ }^{44}$. W listopa-

34 Documenta, nr 9, s. 20-21.

35 Documenta, nr 15, s. 27-28.

36 Documenta, nr 20, s. 37-38.

37 Documenta, nr 21, s. 38-40.

38 Documenta, nr 28, s. 49. W 1322 r. Kerch Olacorum było własnością klasztoru, Documenta, nr 35, s. $59-60$.

39 Documenta, nr 34, s. 55-58.

40 Documenta, nr 49, s. 79-80; L. Kiss, Földrajzi nevek etimológiai szótára, t. 1: A-K, Budapest 1997, s. 684.

41 Documenta, nr 40, s. 66-70. L. Wyrostek, Ród Dragów-Sasów na Węrzech i Rusi Halickiej, Kraków 1932 (nadb. z Rocznika Polskiego Towarzystwa Heraldycznego, t. 11, 1932), s. 6 przesuwa pojawienie się Wołochów nad górną Cisą na $1284 \mathrm{r}$.

$42 \mathrm{~K}$. Kadlec, Valaši a valašské právo v zemích slovanských a uherských, s úvodem podávajícím přehled theorii o vzniku rumunského národa, Praha 1916, s. 232; L. Wyrostek, Ród, s. 6; B. Varsik, Osídlenie Košickej Kotliny, t. 3, Bratislava 1977, s. 371.

43 I. Szabó, Ugocsa megye, Budapest 1937, s. 116-119.

44 A. Rácz, A régi Bihar vármegye településneveinek történeti-etimológiai szótára, Debrecen 2007, s. 209-210 z wnioskiem: „A település a bihari oláhok első nyoma”. Jednak już w 1294 r. odnotowano Wołochów walczących w Biharze po stronie zbuntowanego wojewody Rolanda, zob. Documenta, nr 25 , 
dzie 1338 r. Karol Robert nakazał delimitację posiadłości Bilke, której właścicielem w styczniu był już Wołoch Karachun - to pierwsza wzmianka o osadnictwie wołoskim w komitacie Bereg ${ }^{45}$. Rok wcześniej, w 1337 r. na zgromadzeniu komitatów uskiego, bereskiego i szabolcsskiego panowie z Michaloviec (Nagymihály), właściciele majątku tibawskiego oskarżyli podżupana uskiego Goda Ellésiego z rodu Bár-Kalán, że z ramienia palatyna Wilhelma Drugeta osiedlił Wołochów w leżącej w zachodniej części komitatu uskiego Koromli należącej do dóbr tibawskich, a nie użhorodzkich. W literaturze podkreśla się, że to pierwsza wzmianka o pobycie Wołochów na ziemiach dzisiejszej Słowacji46. Ok. 1340 r. ród Rozgonyich założył w swoim majątku w zemplińskiej Cziczawie wieś Lomne, której grunty sąsiadowały z majątkiem stropkowskim należącym do magistra Loránda, syna bana sławońskiego Mikcsa z rodu Ákos. Ten w 1347 ją spalił, a jak informuje dokument z 1357 r., w najeździe uczestniczyli iobagiones videlicet olahos, ruthenos et alios famulos suos. To najstarsze poświadczenie obecności Wołochów w Zemplinie ${ }^{47}$. W 1344 r. Wołosi przebywali w komitacie Torda w środkowym Siedmiogrodzie ${ }^{48}$, zaś w 1383 r. ich osady były własnością miast saskich, Sybina i Cisnădii/Nagydisznód/Heltau ${ }^{49}$. Najstarszą wzmianką o Wołochach w Szaryszu jest protest właścicieli wsi Kokošovce (Kakasfalva) przeciwko rodowi Sós, którego członkowie osadzili w 1402 r. Wołochów na terenach tej wsi i pozwalali im wypasać stada owiec ${ }^{50}$. Na Spiszu Wołosi pojawili się również na początku XV w., a w 1402 r. prepozyt spiski otrzymał prawo udzielania specjalnego rozgrzeszenia ze względu na obecność Rusinów i Wołochów w okolicy ${ }^{51}$. W 1409 r. spotykamy Wołochów daleko na południu, w leżącej w Borszodzie miejscowości Mezőkeresztes, należącej do zamku Diósgyőr, która w dokumencie Zygmunta Luksemburskiego

s. 42-45; Gy. Györffy, Adatok a románok XIII. századi történetéhez és a román állam kezdeteihez, cz. 1, „Történelmi Szemle” 1964, R. 7, z. 1, nr 24, s. 24.

45 Documenta, nr 51, s. 81 i nr 52, s. 81-83.

46 Documenta, nr 48, s. 78-79; A nagymihályi és sztáray gróf Sztáray család oklevéltára, wyd. Gy. Nagy, t. 1, Budapest 1887, nr 72, s. 120-121 (pełen tekst); B. Varsik, Osídlenie, s. 372; J. Beňko, Osídlenie severného Slovenska, Košice 1985, s. 265; F. Uličný, Dejiny osídlenia užskej župy, Prešov 1995, s. 121. Panowie z Michalowiec to gałąź rodu Kaplyon, zaś Drugetowie należeli do najznaczniejszej nowej arystokracji przybyłej na Węgry z Andegawenami. P. Engel, Magyarország világi archontológiája 1301-1457. Középkori magyar genealógia, Arcanum Digitéka. Magyar Középkori Adattár, Budapest 2001 (płyta CD), Kaplyon nem, tablica 13: Nagymihályi (Jákó ága); idem, Magyarország világi archontológiája 13011457, Budapest 1996 (książka), t. 2, s. 8 (Ellési God); Đ. Hardi, Drugeti. Povest o usponu i padu porodice pratilaca Anžujskih kraljeva, Novi Sad 2012.

47 Opis za: F. Uličný, Dejiny osídlenia Zemplínskej župy, Michalovce 2001, s. 701 i przyp. 85, gdzie cytat z Codex diplomaticus Andegavensis, ed. I. Nagy, Gy. Tasnády Nagy, t. 1-7, Budapest 18781920, tu t. 6, s. 627. Przyczyną zdaniem Autora (ib., s. 281-282) było zapewnienie sobie terenów do rozwoju majątku. Autor błędnie interpretuje zapis jako „valašskí Rusini, či rusinskí valasi”. Tu rację ma J. Beňko, Osidlenie, s. 231, który rozdziela te etnosy, przypisuje jednak miejscowość do Szarysza. O rodach zob. P. Engel, Magyarország (książka), s. 206 (Rozgonyi) i 162 (Mikcsfi).

48 Documenta, nr 71, s. 104-105.

49 K. Kadlec, Valaši, s. 180.

50 B. Varsik, Osídlenie, s. 380; F. Uličný, Dejiny osidlenia Šariša, [Košice] 1990, s. 470.

51 Por. J. Beňko, Osídlenie, s. 174 przyp. 255; H. Ruciński, Hospodárske štruktúry Spiša v neskorom stredoveku, [w:] Historia Scepusii, Vol. 1. Dejiny Spiša, t. 1, s. 386-388. 
określona została jako Valahali Kereztes ${ }^{52}$. Na Liptowie Wołosi osiedli w połowie XV w. we wsi Dubová należącej do majątku likawskiego ${ }^{53}$, skąd przeszli na leżącą na północy Orawę i zasiedlili ziemie należące do Zamku Orawskiego. Przywilej Macieja Korwina z 1474 r. jest najpełniejszym zapisem praw i powinności Wołochów, do których wrócimy poniżej ${ }^{54}$. W 1475 r. król Maciej nadał też przywileje dla Wołochów ze wsi Belá leżącej w majątku Strečna w komitacie trenczyńskim, a ich osadnictwo na północno-zachodnich kresach Królestwa rozwijało się w XVI w. ${ }^{55}$ W 1470 r. Wit z Milštejnu, żupan zwoleński i zarządca komory kremnickiej zezwolił Wołochom na osiedlenie się nad górnym Hronem, na ziemiach należących ad castrum Lipcz, czyli Slovenskej Lupčy w komitacie gemerskim ${ }^{56}$. W XV i XVI w. wzmiankowani są też m.in. na ziemiach Krasnej Horki, Plešivca, Rožňavy oraz Murania ${ }^{57}$.

Jak widzimy, w świetle pierwszych wzmianek w dokumentach o Wołochach można zrekonstruować ich wędrówkę od Gor Fogaraskich, centralnego masywu Południowych Karpat przez Góry Biharskie oraz tereny sięgające po Żelazną Bramę, czyli przełom Dunaju opuszczającego Basen Karpacki (tu jeszcze w XIII w.) aż po stoki Wschodnich Karpat w Marmaroszu (pewna wzmianka w dokumencie pochodzi z 1326 r.). Potem postępują wzdłuż łuku Karpat zasiedlając słabo zaludnione obszary górskie aż po granicę węgiersko-morawską i węgiersko-śląską. Wydaje się, że zasiedlili góry co najmniej do rzeki Hron, a nawet przekroczyli ją w górnym biegu dochodząc do komitatu zwoleńskiego, zaś na zachodzie do miast bańskich oraz w okolice Trenczyna $^{58}$. Natomiast źródła nie wykazują hodowli owiec w majątku zamku Likava/ Čabrad' w Małym Honcie ${ }^{59}$. Tu zatem kończył się zasięg kolonizacji wołoskiej, która na zachód przekraczała granicę śląską i morawską ${ }^{60}$. Nie przeniosła się ona dalej na ziemie sudeckie czy Wysoczyznę Czesko-Morawską. Przyczyny przekonująco wyjaśnił Václav Chaloupecký, który zauważył, że w Czechach hodowla owiec zaczęła się w XVI w., gdy z Maghrebu przez Hiszpanię i Włochy napłynęła technologia wyrobu

52 G. Klein, R. Péchy-Horváth, Mezőkeresztes, [w:] Borsod vármegye (Borsod, Gömör és Kishont K. e. e. vármegyek), red. A. Csíkvári, Budapest 1939 (Vármegyei szociográfiák, t. 5), IV rész: Községi adattár, s. 89-90; B. Varsik, Osídlenie, s. 374-375.

53 J. Beňko, Osídlenie, s. 137.

54 J. Beňko, Osidlenie, s. 69.

55 J. Beňko, Osidlenie, s. 30-31.

56 V. Chaloupecký, Valaši na Slovensku, Praha 1947, s. 23 i przyp. 26.

57 V. Chaloupecký, Valaši, s. 44-45; O. Tomeček, Valasi na území Zvolenskej stolice, [w:] Valašská kolonizácia na Slovensku a slovenská kolonizácia v Rumunsku. Zborník príspevkov z 10. zasadnutia Komisie historikov Slovenska a Rumunska (Banská Bystrica, 25.-27. september 2012), Banská Bystrica 2014, s. 27-39.

58 V. Chaloupecký, Valaši, s. 47-60. T. Cojocaru, Vlachs in Slovakia and Poland. Some preliminary considerations, [w:] Valašská kolonizácia, s. 26 (jest to angielskie streszczenie jej artykułu Valasi na Slovensku a v Pol'sku. Predbežné úvahy, ibidem, s. 20-26) twierdzi, że do Zemplina i Gemeru kolonizacja wołoska dotarła bezpośrednio z Bałkanów przez Wielką Nizinę Węgierską. Z braku dostępu do pełnej treści artykułu nie znam argumentacji autorki, możliwość ta wydaje mi się jednak nieprawdopodobna.

${ }^{59}$ P. Maliniak, Čabradské panstvo v stredoveku, Banská Bystrica 2019, s. 145: „Je zrejme príznačné, že o ovčiarstve a salašníctve chýbajú doklady".

60 D. Krandžalov, Valaši na Moravě. Materiály, problémy, metody, Praha 1963. 
tkanin z owczej wełny. Zaczęto więc hodowlę na wełnę, a w dalszej kolejności mięso i tłuszcz. Tymczasem hodowla wołoska nastawiona była na mleczarstwo i serowarstwo. Czechy należały zatem do zachodnioeuropejskiego obszaru gospodarczego, owczarstwo miało w nich taki charakter, jak np. w krajach niemieckich, podczas gdy kolonizacja wołoska sięga korzeniami Bałkan ${ }^{61}$.

\section{ZAJĘCIA, OBCIĄŻENIA I INSTYTUCJE PRAWA WOŁOSKIEGO}

Zarysowany wyżej obraz burzy przytoczona przez László Makkaia za Györgym Györffym zapiska z 1214 r. (w rzeczywistości z 1219 r.), gdzie czytamy: Villani kenesii et omnes alii de provincia Doboka ${ }^{62}$. Pada tu nazwa kniaziów, podstawowej instytucji prawa wołoskiego. Zdaniem László Makkaia musi tu chodzić o Słowian, gdyż „Rumuni” w tym komitacie (po rumuńsku Dăbâca) jeszcze nie mieszkali, zatem instytucja ta ma korzenie słowiańsko-węgierskie będąc wytworem węgierskiego feudalizmu przejętym w Siedmiogrodzie przez „Rumunów” (jak konsekwentnie pisze Autor o Wołochach), zaś o pierwotnej organizacji „rumuńskiej” nie wiemy nic ${ }^{63}$. Bliższe przyjrzenie się tej zapisce każe odrzucić to przypuszczenie znakomitego znawcy stosunków węgiersko-rumuńskich.

Zapiska przytaczana w Geografii historycznej György Györffyego pochodzi z waradyńskiego rejestru stosowania ordaliów. Była to dopuszczona prawem w wiekach średnich procedura dowodzenia swoich racji przez poddanie się próbie wody (podtapiania) oraz żelaza (branie do ręki rozżarzonego żelaza) ${ }^{64}$. Protokoły zostały wydane drukiem w 1550 r., a reprint wraz z komentarzami i przedrukiem w porządku chronologicznym z imionami dostosowanymi do współczesnej ortografii węgierskiej wydali w 1903 r. János Karácsonyi i Samu Borovszky, którzy udowodnili, że zapiski pochodzą z czasów Andrzeja II i obejmują lata 1208-1235. Interesująca nas zapiska nr 227 (wg numeracji inkunabułu 97) pochodzi z września 1219 r. ${ }^{65}$ Głosi ona, że

61 V. Chaloupecký, Valaši, s. 9.

62 Kurze Geschichte, s. 192 podana za: Gy. Györffy, Az Árpád-kori Magyarország történeti földraj$z a$, t. 2, Budapest 1987, s. 66.

${ }^{63}$ Kurze Geschichte, s. 192-193. Bardziej przekonują wcześniejsze poglądy László Makkaia. Pisanie o Rumunach oraz koncentrowanie się w pracach o nich na księstwach rumuńskich jest cechą prac węgierskich, zob. np. znakomite studium L. Makkaia, Magyar-román közös múlt, wyd. 2, bmw. 1989 (wyd. 1 1947), gdzie jednak mowa głównie o Wołoszczyźnie (Havaselve) i Mołdawii; A. Du-Nay, A román nép kialakulása s korai története, Bp. 2004 (analiza z punktu widzenia językoznawstwa); A. Miskolczy, Románok a történeti Magyarországon, Budapest 2005.

64 W. Maisel, Archeologia prawna Europy, Warszawa-Poznań 1989, s. 185-187.

65 Regestrum Varadinense examinum ferri candentis ordine chronologico digestum descripta effigie editionis a. 1550 illustratum sumptibusque Capituli Varadinensis Lat. Rit. curis et laboribus Joannis Karácsonyi et Samuelis Borovszky Academiae Scientiarum Hungaricae membrorum editum, Budapest 1903, s. 88 (przedmowa po łacinie), 124 (przedmowa po węgiersku). Wydanie zawiera faksymile edycji z 1550 r., oraz w osobnej paginacji obszerny komentarz po łacinie i węgiersku, zestawienie urzędników 
Villani Kenesy scilicet Kereu Vruz, Micus \& omnes alij de prouincia Doboka, litigauerunt coram Turdemetz curiali comite de Canar, cum villanis Peleca scilicet Turuzo, Ioleguen, Gyok \& alijs pro terra ad duo aratra \& ducentis capecijs frugum, dicentes, quod illam terram uiolenter occupantes coluissent, villani vero de pelenka responderunt, Quod terra Castri \& propria terra eorum esset. Quos prędictus Iudex Turdemez discuciens per pristaldum Ochy de villa Scenta, misit ad examen ferri Varadinum, vbi homo villanorum Kenesi nomine Petrus, combustus est ${ }^{66}$.

A zatem wieśniacy kneziowie Kerew, Uruz, Micus i inni z komitatu Doboka spierali się przed Turdemesem, komesem dworskim z Canar o dwa pługi ziemi i dwanaście korców zboża z wieśniakami z Peleki Turuzem, Jolegvenem, Gyokiem i innymi. W wyniku zastosowanej próby ognia jeden z keneziów o imieniu Piotr spłonął. W wykazie pojawiają się też wojewodowie, np. quidam potens, nomine Voiavoda ${ }^{67}$. Termonologia ta wskazywałaby na osadnictwo wołoskie.

Nasuwa się zatem inne rozwiązanie tak wczesnego poświadczenia domniemanej obecności Wołochów. Wiadomo, że zachowana do dziś podstawa źródłowa nie odzwierciedla całości procesów, jakie zachodziły na danym terenie i szczególnie z odleglejszych epok jest wybiórcza i przypadkowa. Można sobie wyobrazić, że osadnictwo Wołochów na początku XIII w. było bardziej rozpowszechnione, niż wydawało się na podstawie zachowanych dokumentów i że osady stałe powstawały również wcześniej, nawet jeśli tylko grupy Wołochów osiedlały się w już istniejących osadach. Zapiska z 1219 r. nie byłaby zatem dowodem na słowiańsko-siedmiogrodzki autochtonizm tytułu kniazia, lecz świadectwem wcześniejszego, niż dotąd przyjmowano, osiedlania się Wołochów. A co istotne, zapiska z 1219 r. zgadza się z przekazem Anonima węgierskiego, przywoływanym w początkowej części tych rozważań, że w okolicy Porta Mezesyna znajdowało się państwo Wołochów i Słowian księcia Gelou. Zdaje się pokrywać geograficznie z terenem, którego dotyczyła zapiska. Doboka leży mianowicie na północny wschód od Przełęczy Mezeskiej. Można sobie wyobrazić, że już na przełomie XII i XIII w. istniało tam osadnictwo wołoskie i zaczątki stałych osad, ktorych mieszkańcy parali się rolnictwem. Jest to oczywiście na obecnym etapie wyłącznie hipoteza robocza.

Wspomniany już wyżej dokument Béli IV z 1247 r. nadający ziemie joannitom w Banacie Szörény (Severin) włącza do nadania kniaziostwa Jana i Farkasa (to drugie imię wskazywałoby, że był on Węgrem, albo też, że węgierski pisarz dokumentu

(archontologię) z poszczególnych lat, które obejmowały zapiski oraz nowoczesną transkrypcję starodruku z $1550 \mathrm{r}$

66 Ritvs explorandae veritatis, qvo Hvngarica natio in dirimendis controuersijs ante annos trecentos \& quadraginta vsa est, \& eius testimonia plurima, in Sacrario summi temple Varadiensi reperta, Colosuarij 1550, składka D3, k. 2v, [w:] Regestrum j.w. Z przyczyn technicznych nie oddaję długiego s oraz rozwiązuję skróty na spółgłoskę nosową ' $n$ '. Tekst w zmodernizowanej łacinie, ibidem, s. 238. Scenta to Csente w komitacie Doboka. Urzędników nie wymienia A. Zsoldos, Magyarország világi archontológiája 1000-1301, Budapest 2011 ani P. Engel, Magyarország világi archontológiája (książka).

${ }^{67}$ Zapiska nr 212 (44), s. 230-231. Zapiska pochodzi również z 1219 r., zob. ibidem, s. 88 i 123. Inni wojewodowie pojawiają się w zapiskach: s. $181 \mathrm{nr} 78$ (304); s. 270, nr 311 (362); s. 201, nr 134 (283), ale w ich przypadku mam wątpliwości, czy chodzi o wojewodów wołoskich. 
przełożył imię Lupu albo Vuk), zaś wyłącza kniaziostwo wojewody Lytuoya (Litvaja) oraz wojewody Senesława ${ }^{68}$. To pierwsza wzmianka o kniaziach i wojewodach wołoskich, jeśli nie liczyć przywołanej wzmianki z Doboki z 1219 r. W 1263 r. młodszy król Stefan (V) nadał Ponytowi z rodu Miskolc, przodkowi Szécsych m.in. wieś Fenes w komitacie Hunyad exceptis terris Dragun et Kodoch kenasys ${ }^{69}$. Termin ten znany był też magistrowi Rogerowi, który określił nim w jednym miejscu możnego Austriaka, który pospieszył na pomoc swemu księciu zrzuconemu z konia przez Tatara $^{70}$, w innym dla określenia urzędników tatarskich pilnujących jeńców ${ }^{71}$. Świadczy to o znajomości tego słowa w Siedmiogrodzie i że kojarzyło się ono ze średnim szczeblem władzy.

Wydaje się, że rację miał László Makkai, gdy w 1947 r. określił kniaziów, inaczej sędziów (judec) jako przywódców grupy krewniaczej. Przytacza słowa Miklósa Bethlena, który w XVII w. pisał o Wołochach: „Żyją w głębokich dolinach niczym w wielu osobnych małych państwach i z większością mieszkańców Siedmiogrodu właściwie się nie kontaktują. Głowa rodziny jest jednocześnie kapłanem i sędzią, który rano i wieczorem prowadzi modlitwę za domowników oraz wymierza sprawiedliwość" 72 . Z chwilą porzucania nomadycznego trybu życia i osiedlania się w Siedmiogrodzie, a później w innych częściach Królestwa Węgierskiego, rola kniazia się zmieniała - stawał się założycielem i przywódcą wioski. Nasuwa się tu oczywiste porównanie $\mathrm{z}$ zasadźcą, który stawał się sołtysem prawa niemieckiego ${ }^{73}$. Bo istotnie, jak widzimy, już w XIII w. zaczęło powstawać stałe osadnictwo wołoskie. Osiedlano ich na ziemi nieprzyjaznej dla uprawy roli, na której głównym zajęciem mogła być tylko hodowla zwierząt. I takie właśnie umiejętności przyniósł ten pasterski lud, choć nie stronił również od uprawy ziemi, gdzie się dało, oraz od rzemiosła. Najbardziej był znany z serowarstwa, a produkowane przez nich rodzaje serów przetrwały wieki wchodząc do kulinarnego dziedzictwa narodów, które Wołochów zasymilowały.

68 Documenta, nr 9, s. 20-21, por. wyżej, przyp. 34. Zob. także L. Tamás, Rómaiak, románok és oláhok Dácia Trajánában, Budapest 1935, s. 195-196; Kurze Geschichte, s. 193.

${ }^{69}$ Kurze Geschichte, s. 194. Tekst: Gy. Györffy, Adatok, s. 7-8 i przyp. 29.

${ }^{70}$ An. ang. (wydanie zawiera również Lament Rogera), rozdz. 23, s. 170 i 171 z przyp. 4, gdzie domysł, że termin ten „may have been known to Roger as the term for leaders of groups or villages of Vlachs (Romanians)".

${ }^{71}$ Ibidem, rozdz. 35, s. 208-209.

${ }^{72}$ L. Makkai, Magyar-román, s. 24: Völgyeik mélyén élnek, mint megannyi külön kis köztársaságban $s$ Erdély többi lakóival egyáltalán nem érintkeznek. A családfö egyúttal pap és bíró, aki reggel, este imádkoztatja a házanépét és igazságot oszt.

73 Już K. Kadlec, Valaši, s. 261 zauważył, że prawo wołoskie było „vlastnĕ jen modifikací „práva německého" [--]. Rozdíly mezi vesnicemi podle práva německého a vesnicemi podle práva valašského vyplývaly jen ze zvláštního zaměstnání obyvatelstva. Kdežto v osadach podle práva nĕmeckého živili se sedláci zemědělstvím, zabývali se kolonisté vesnic valašských převážně pastevectvím”. Por. F. Uličný, Dejiny osídlenia Užskej župy, s. 310: „Označenie kenezov slovom šoltýs sa dochovalo od 16. storočia a v 17. storočí bolo pre nich všeobecným (jediným) označením”. Idem, Dejiny osídlenia Zemplínskej župy, s. 701 przyp. 88 zauważa, że funkcja knezia występuje w Zemplinie tylko raz jako imię ojca sołtysa we wsi Potočky koło 1557 r. Była to chyba najbardziej na zachód wysunięta wzmianka o tej godności. 
Wołosi osiedlali się początkowo wyłącznie na ziemi należącej do monarchy. Dopiero Władysław IV Kumański zezwolił na ich osiedlanie się na gruntach należących do instytucji kościelnych ${ }^{74}$ oraz na gruntach prywatnych ${ }^{75}$. W XIV i XV w. powstawały np. osady wołoskie na gruntach miast spiskich, a osadnicy mieli status ludności zależnej od mieszczan ${ }^{76}$. Jak zezwolił na to już Andrzej III w przywoływanym dokumencie ${ }^{77}$, kneziowie razem z podległymi sobie ludźmi zobowiązani byli do uiszczania opłat za prawo osiedlania się. Nie zawsze zresztą wywiązywali się ze swych obowiązków. Tak np. kapituła siedmiogrodzka po 20 czerwca 1331 r. w wykazie przychodów odnotowała, że Adrianus decanus exactor quinquagesime nostre olacalis de omnibus kenezis nostris pro debitis ipsorum nakazał zapłacić im dziewięć i ćwierć grzywny czystego srebra (novem marcas et fertonem fini argenti) oraz mówiąc w imieniu kapituły kenezio nostro de Nirmezeu, że są zwolnieni z zapłaty trzech czwartych grzywny (zaległość wynosiła 10 grzywien). Piąta część tej sumy, czyli grzywna i trzy czwarte przypadła prepozytowi, zaś trzy trzydzieste drugie grzywny przypadły przez prokuratora magistra Andrzeja biskupowi ${ }^{78}$. Nie był to koniec pobranych tego roku danin. Item eodem anno et die idem magister Adrianus de ipsis kenezis et zondis nostris presentaverit nobis viginti birra, que vulgariter cherge [dicuntur], et quatuordecim caseos $^{79}$.

Jak widać, kneziowie wołoscy z Nyírmező w komitacie Alsófehér (Alba de Jos) płacili pięćdziesiątnicę (quinquagesima), czyli po dwie owce ze stu ${ }^{80}$, dwadzieścia kocy i czternaście serów. Pokazuje to, że głównym obszarem ich działalności było pasterstwo i związane z nim rzemiosło przetwarzające produkty odzwierzęce. Po trzystu latach tak opisywał je cytowany już wyżej Miklós Bethlen: „Pod koniec lata gospodarze opuszczają swoje doliny, aby mogli zagnać swoje owce do wód w sąsiedztwie wołoskiego Dunaju, gdzie wśród krzewów jeszcze zimą owce mogą znaleźć świeżą trawę. Wiosną natomiast wracają ... i tak [bardzo] wycofując się żyją w towarzy-

${ }^{74}$ Gy. Györffy, Adatok, s. 10 oraz nr 19, s. 22.

75 Gy. Györffy, Adatok, nr 21, s. 22 - dokument Andrzeja III z 16 czerwca 1292 r. wystawiony dla Sándora, syna Gurka z rodu Ákos, zezwalający mu, ut ad quasdam terras suas hereditarias, Elye, Zad et Fenes vocatas Olacos possit aggregare et aggregatos retinere, omnem collectam ac debitam eorundem Olacorum predicto Alexandro relinquentes.

${ }^{76}$ K. Kadlec, Valaši, s. 178-185 oraz 278nn.

77 Ibidem, przyp. 75 .

${ }^{78}$ De quibus deducta quinqua parte prepositi videlicet septem fertonibus et tribus secinis per magistrum Andream procuratorem domini episcopi. Documenta, $\mathrm{nr} 42$, s. 70-71 i przyp. 2 s. 70, gdzie wyjaśnienie, że chodziło o grzywnę siedmiogrodzką liczącą 206,76866 gramów. Ferto to ćwierć grzywny (por. I. Bogdán, Metrológia, [w:] A történelem segédtudományai, red. I. Bertényi, Budapest 1998, s. 345: fertály, kwartale, szapu, véka), zaś secinus względnie sectinus to 1/32 grzywny.

${ }^{79}$ Documenta, $\mathrm{nr}$ 42, s. 71. Wg słownika języka węgierskiego z XIX w. (G. Czuczor, J. Fogarasi, A magyar nyelv szótára, Pest 1862, t. 1, kol. 965: „Csérge: Székely szó, jelent, a közönséges lópokrócznál valamivel szebb takarót, melylyel a szegény emberek takaródznak. Van lócserge is, melyet lóra terítenek", https://mek.oszk.hu/05800/05887/pdf/1kotet_2.pdf [dostęp: 01.02.2020]. Jak widać, chodzi o koce, pokrowce, opończe. Pojawiające się słowo (w ablatywie pluralis) zondis jest latynizacją słowiańskiego słowa: 'sędzia', 'sędziowie'.

${ }^{80}$ Kurze Geschichte, s. 195. 
stwie swoich owiec w wysokich górach, że nie dbają o sąsiedztwo i o to, co się dzieje na świecie" "81. László Makkai słusznie komentuje te słowa, że jest to obraz pasterstwa transhumacyjnego ${ }^{82}$. Obok owiec wypasali również świnie.

$\mathrm{Z}$ terenu XIV-wiecznego Siedmiogrodu mamy jeszcze dalsze wzmianki o charakterze gospodarki Wołochów. 4 lipca 1357 r. król Ludwik zwolnił z płacenia quinquagesimy ze wszystkich posiadłości wołoskich w Siedmiogrodzie należących do Tomasza, syna Dionizego, jego synów i rodziców ${ }^{83} .20$ marca 1360 r. Ludwik nadał wsie w Marmaroszu Draguszowi, synowi Gyuli, fidelis noster Olachus de Maramarusio w uznaniu jego zasług w zwalczaniu buntu w Mołdawii cum proventibus nostris quinquagesimalibus, collectis debitis et aliis utilitatibus universis nove donationis titulo ${ }^{84}$. Z kolei 16 maja 1366 r. ochrzcił się w wierze rzymsko-katolickiej Sorban z Ócsvy, który na chrzcie przyjął imię Stefana i w nagrodę otrzymał posiadłość królewską Kisachwicha, dziś Aciuţa - Ácsfalva w komitacie csanádzkim (dziś regionie aradzkim) pod warunkiem, że będzie uiszczał quinquagesimam ovium et decimam porcorum $^{85}$. Przyjrzyjmy się jeszcze statutom kapituły waradyńskiej z 1374 r., która in districtu vero de Zeplak, czyli w rejonie dzisiejszej miejscowości Suplac Tenkeszéplak w Biharze odnotowała villas Olachales. Wszyscy poddani mają ujednolicone obciążenia na rzecz kapituły

praeter subditos nostros Olachales, qui ritu adhuc gentilitatis viventes, differunt omnino ab Hungaris in dandis collectis. Ipsi enim pro censu annuo teneantur singuli singulariter annis singulis circa festum Pentecostes dare decimam partem ovium suarum, ratione quinquagesime; circa festum vero Nativitatis beate Marie virginis singule mansiones oves singulas ratione descensus, et de mense Decembris vel circa similiter decimam porcorum suorum. Kenezii vero tam ad ovium quam porcorum prestationem astringuntur iuxta conventionem factam inter nos et eosdem, et ultra hoc iidem Kenezii singulariter de more consueto dant circa ... annis singulis, medium lodicem, unum filtrum pro sella et unum caseum. Communiter vero Olahi nostri dant nobis in die Strennarum in signum dominii annis singulis equum unum.

${ }^{81}$ L. Makkai, Magyar-román, s. 24: Völgyeiket ezek a gazdák nyár végén hagyják el, hogy juhaikat az oláhországi Duna melléki vizekre hajtsák, ahol a bokrok közt még télen is friss füvet találnak a juhok. Tavasszal azután visszatérnek ... s oly visszahúzódva élnek juhaik társaságában a havasokban, hogy egyáltalán nem törödnek környezetükkel és azzal, ami a világban történik.

82 L. Makkai, Magyar-román, s. 24.

83 Documenta, nr 97, s. 133-134. Chodziło zapewne o Tomasza, żupana szeklerskiego z rodu Tomaj, rodziny Losoncich, przodka Bánfich. P. Engel, Magyarország világi archontológiája (płyta CD), Tomaj nem, tabl. 2: Losonci. Mieli oni swe posiadłości w komitatach Szolnok-Doboka i Maros-Torda.

84 Documenta, nr 109, s. 144-145. Ludwik Wyrostek uznał go za namiestnika węgierskiego w Mołdawii i protoplastę rodu Drágffich. L. Wyrostek, Ród, s. 9-10 (analiza tego dokumentu); P. Engel, Magyarország világi archontológiája (płyta CD), Drágfi (bélteki) z odwołaniem do pracy L. Wyrostka.

${ }^{85}$ Documenta, nr 148, s. 189-190. Por. też dok. nr. 152, s. 201 (opłata quinquagesimam ovium nobis annuatim de quadam possessione Olachali Mohal vocata in comitatu de Doboka situate, quam ipse magister Deseu suam fore asserit). 
Wśród innych źródeł dochodów kapituły wymienia się illa, que consistunt in decimis porcorum, agnorum, hedorum et mellis sive apum, ac in omnibus ratione descensus et quinquagesime Wolachorum ${ }^{86}$.

Jak widzimy, przez XIV-wieczne źródła siedmiogrodzkie przewijają się daniny $\mathrm{z}$ owiec (przy czym zazwyczaj jest to quinquagesima ${ }^{87}$, zakładająca oddanie $\mathrm{w}$ ramach daniny dwóch owiec ze stu, tylko kapituła waradyńska zdołała narzucić dziesięcinę, zresztą pod starą nazwą). Oprócz tego znajdujemy daninę płaconą w świniach i kozach, przy czym świnie oddawało się w grudniu, quinquagesimę późną wiosną na Zielone Świątki. Dodatkowo na święto Narodzenia NMPanny 8 września oddawano owcę. Kneziowie na podstawie zawartych umów oddawali jeszcze narzutę średniej wielkości, filc na siodło i jeden ser. Dodatkowo wspólnota wołoska na Nowy Rok dawała jednego konia ${ }^{88}$.

Z XV w., kiedy kolonizacja wołoska w Królestwie Węgierskim objęła większość Zachodnich Karpat, posiadamy stosunkowo mało dokumentów lokacyjnych wsi na prawie wołoskim, do tego stopnia, że Beňko, chcąc określić powinności zemplińskich osad, przywołuje przywilej z połowy XVI w. dla Dołżycy leżącej w starostwie sanockim, a zatem po drugiej stronie gór ${ }^{89}$. Wyjątkiem jest przywilej Macieja Korwina dla Wołochów orawskich z 1474 r. Wystawiony on został na prośbę mieszkańców ze wsi Kňažia oraz Medzibrodie należących do Zamku Orawskiego oraz wsi Dubová, własności majątku likawskiego chcących potwierdzenia dawnych praw swych przodków. Mieszkańcy zatem: 1. zostali zwolnieni z płacenia podatków państwowych; 2. zostali zwolnieni od robocizny na zamkach, do ktorych należeli; 3. mógł ich sądzić tylko wojewoda wołoski, którego wspólnie wybierali, zaś apelację zgłaszali żupanowi albo bezpośrednio władcy; 4. zostali zwolnieni z zapłaty podatków, cła i myta na towary wiezione na targ albo kupione na własne potrzeby z wyjątkiem towarów, z których czerpali zysk; 5. mogli paść owce w lasach obu zamków, a poza tym w odległości do jednej czwartej mili, gdyby zaś zwierzęta weszły w szkodę sąsiadom, mieli dać jako rekompensatę sześć owiec; 6 . z owiec i kóz każdy miał dać co dwudziestą, czyli obowiązywała vigesima, mniej korzystna niż quinquagesima (zamiast dwóch, płacono pięć owiec ze stu ${ }^{90}$; 7. każdy posiadacz owiec co roku miał dać też jednego skopa

${ }^{86}$ Documenta, nr 214, s. 255-257 za wydaniem V. Bunyitay, A váradi káptalan legrégibb statutumai, Nagyvárad 1886. Tekst Statutów zaczyna się od Kroniki waradyńskiej, ekscerpty z której zostaną wydane w Testimoniach najdawniejszych dziejów Stowian, seria łacińska, t. 3: Średniowiecze, z. 1: Źródła węgierskie, przygotowywanych w ramach grantu afiliowanego przy Instytucie Slawistyki PAN. Por. K.Kadlec, Valaši, s. 209.

87 Pobierano ją jeszcze w połowie XVI w., K. Kadlec, Valaši, s. 209 i 210: „Padesátek jakožto dávka pastýřská udržel se jen v Sedmihradsku - v Uhrách [--] Valaši zdaněni po spůsobu ostatního selského lidu --., s. 259 (wzmianka o rejestrze wsi z 1461, z których pobierano tę daninę). Por. też O. Tomeček, Valasi, s. 31 przyp. 17.

${ }^{88}$ Charakterystyka powinności zob. też K. Kadlec, Valaši, s. 208n.

89 J. Beňko, Osídlenie, s. 271-272.

$90 \mathrm{~W}$ dokumencie z 1506 r. potwierdzającym nadanie kneziostwa wojewodzie Władysławowi ze Sztánfalva/Stanovca w komitacie marmaroskim przez Elżbietę z Szilágich, żonę Jánosa Hunyádyego, pojawia się nazwa proventus sztrangarum, stranga, która w polskich źródłach zapisywana jest jako stra- 
(wykastrowanego barana) i popręg, zaś posiadacz wołów grosz za każdego rocznie; 8. w zamian od zwolnienia od danin i pańszczyzny każdy zbrojnie, zwłaszcza z kuszą, miał strzec dróg przed rabusiami i złodziejami; 9. na polecenie żupana uzbrojona młodzież miała się stawić w wyznaczonym przez niego miejscu, aby zabezpieczyć przejazd dygnitarzom. Gdyby ktoś wzbraniał się stawić z bronią, na każde wezwanie żupana powinien zapłacić po 6 owiec, zaś po trzecim wezwaniu tracił majątek, który przechodził na własność króla ${ }^{91}$. Dokument został potwierdzony i rozszerzony na Wołochów ze wsi Bziny oraz Ústie z taką zmianą, że rozciągnął na nich obowiązek zapłaty podatku państwowego - tricesimy oraz nakazywał służbę już nie z kuszami, lecz z rusznicami ${ }^{92}$. Nałożenie tego podatku w drugiej połowie XVI w. jest chyba największą różnicą, którą przynoszą czasy nowożytne. Jednak zachował się wołoski system danin. Tak np. sołtys i poddani w miejscowości Vel'krop w majątku stropkowskim w Zemplinie płacili od połowy XVI w. rocznie floren i 25 denarów. Sołtys z tytułu koszarowania powinien oddać rocznie 6 owiec, gazdowie oddawali co dwudziestą owcę (czyli była to vigesima), dziesięcinę z jagniąt i ze świń, zaś na Wielkanoc dodatkowo oscypek albo ser oraz pasek do siodła ${ }^{93}$.

W 1523 r. żupani mukaczewscy Grzegorz z Rakomazu i Andrzej z Szentmihályi na wniosek zarządcy zamku, biskupa wacowskiego Istvána Vardai, nadali Łazarzowi, kneziowi Kalnika oraz jego stryjecznemu bratu Maciejowi kneziostwo w osadzie, którą mieli założyć i nazwać Lazarfalva. Kneziowie mieli prawo do jednej trzeciej kar, założenia młyna i folusza. Czynsz mieli płacić dwa razy do roku, na św. Jerzego (czyli 23 kwietnia) oraz na św. Michała (29 września) po 50 denarów. Kto hodował ponad 10 świń, musiał jedną oddać na potrzeby zamku, kto mniej, wpłacał portiones solitas. Osadnicy otrzymywali 14 lat wolnizny ${ }^{94}$.

I jeszcze przykład z 1580 r. z północno-zachodnich kresów Królestwa. Chodzi o założenie na prawie wołoskim Terchowej w majątku Streczno w północnej części komitatu trenczyńskiego na pograniczu Kysuc i Turca. Właściciele „państwa” Strečno

ga, a w źródłach orawskich z XVII w. stronga, por. K. Kadlec, Valaši, s. 262 i 358. Na s. 275 definicja: „počítání ovcí za příčinou zjišstění dávky z nich”. O. Tomeček, Valasi, s. 31 przyp. 17 również zauważa, że na dzisiejszej Słowacji pobierano vigesimę.

91 Omawiam za: J. Beňko, Osídlenie, s. 69-70. Tekst dokumentu: J. Gagyi, Az árvavármegyei oláh telepek kiváltságlevele, „Történelmi Tár” 1910, s. 189-191 z błędną datacją na 6 marca 1474 r. Datę powtarza K. Kadlec, Valaši, s. 271, 494-496. Tymczasem dokument datowany jest in oppido Rosemberk [czyli chodzi o Ružomberok w zachodnim Liptowie], feria quinta proxima ante dominicam Ramispalmarum anno domini millesimo quadringentesimo septuagesimo quarto, czyli na czwartek przed Niedzielą Palmową, czyli na 31 marca $1474 \mathrm{r}$.

92 ...excepta ea clausula, in qua de relaxatione contributionis generalis regni agitur; saluis etiam tricesimis nostris et ea parte, qua scriptum est, ut coloni praescriptarum possessionum pro custodia viarum arcus manuales et balistas habere debeant, quarum loco eo, quod usus arcuum et balistarum nunc desierit, scloppos manuales pro praesentis temporis ratione ipsos habere volumus, J. Gagyi, Az ärvavármegyei, s. 193; J. Beňko, Osídlenie, s. 72 . K. Kadlec, Valaši, s. 267 przytacza dekret Sejmu węgierskiego z 1563 r., który pasterzy pozbawionych stałych domów zobowiązuje do zapłaty tylko połowy normalnej daniny,

93 J. Beňko, Osídlenie, s. 273.

94 Podaję za: K. Kadlec, Valaši, s. 261-262. 
podpisali umowę z Jurajem Mudranom, który stawał się sołtysem ${ }^{95}$. Osadnicy otrzymali 12 lat wolnizny, zaś potem mieli odprowadzać od roli po pięć baranów i tak samo pięć baranów od stu owiec (czyli wołoska vigesima). Sołtys miał uiszczać takie podatki, jak inni sołtysi, miał prawo warzyć i sprzedawać piwo oraz wystawić młyn. Wszyscy gospodarze mieli na wezwanie właściciela stawić się zbrojnie na zamku. W 1609 r. od łąki zwanej Kral'ova dawano na św. Michała (29 września) po dwa czerwone sery (oscypki oraz wędzone) albo jeden floren, 1 'tunu' bryndzy, dzierżę masła wartości florena, zaś na Matki Boskiej Gromnicznej (2 lutego) po jednej pięknej kunie albo dukacie czerwonego złota ${ }^{96}$.

Zmiany w sposobie gospodarowania prowadziły do zakładania stałych przysiółków na zboczach gór oraz wydzielania tam poletek uprawnych ciągnących się przez cały obszar jednostki osadniczej. Powstawały od przełomu XVI i XVII w. rozproszone osady pozbawione centrum. Osadnicy otrzymywali od 6 do 20 lat wolnizny, a potem oddawali vigesimę z żywego inwentarza, skórki kunie, bryndzę, niekiedy obowiązani byli do służby zbrojnej. Oddawano też część plonów, jajka, kury. Specyfiką było karczowanie lasów, obróbka drewna i zamienianie lasów na uprawne pola, co odróżniało ten sposób osadnictwa od klasycznego wołoskiego. Dlatego Ján Beňko uznaje ten typ za osobny rodzaj osadnictwa ${ }^{97}$. Moim zdaniem można tu mówić raczej o ewolucji osadnictwa wołoskiego, dostosowaniu się do przemian gospodarczych zaszłych w czasach nowożytnych. Określił on zresztą krajobraz kulturowy słowackich, ale i polskich gór (Beskidów i Tatr) ${ }^{98}$.

Pogorszenie się sytuacji ludności wołoskiej w czasach nowożytnych obserwujemy na całym obszarze kolonizacji wołoskiej w Królestwie Węgierskim i w Siedmiogrodzie. Karel Kadlec opisuje położenie ludności wołoskiej w osadach należących do miast saskich. O ile pod koniec XIV w. mieszkańcy miejscowości Resinár - Răşinari zobowiązywani byli przez miasto Sybin do strzeżenia granicy w Karpatach, to mieszkańcy wsi Popláka - Poplaca w 1584 r. mieli pomagać przy budowie umocnień miejskich w Sybinie i odbywać poselstwa w czasie wojny, a poza tym zaopatrywać żniwiarzy, dowozić drewno, służyć urzędnikom, pomagać

95 Pojęcie knezia znika ze źródeł pod koniec XIV w. w Zemplinie, zastępowane przez sołtysa to wpływ istniejącego na tych terenach już wcześniej prawa niemieckiego. F. Uličný, Dejiny osidlenia Zemplínskej župy, s. 702 i przyp. 90 odnotowuje jedyną wzmiankę o keneziu w Zemplinie pochodzącą z 1402 r. K. Kadlec, Valasi, s. 276 pokazuje upadek znaczenia kneziów - sołtysów w XVIII w., kiedy od reszty ludności poddańczej różnili się tylko tym, że nie byli obarczeni obowiązkiem pańszczyzny.

96 J. Beňko, Osídlenie, s. 36 i przyp. 198. K. Kadlec, Valaši, s. 263 zwraca uwagę, że w komitacie bereskim spotykamy zróżnicowanie wolnizny w zależności od rodzaju posługi, np. list z 1579 r. dla Iwaszki Grozowicza Wisznickiego na założenie nowej osady annorum sex libertas a censu solvendo, a servitiis vero praestandis ad annos tres.

97 J. Beňko, Osídlenie, s. 39-41: kopaničiarske právo, prawo kopanickie. K. Kadlec, Valaši, s. 263 wspomina o zlaniu się prawa niemieckiego i wołoskiego w XVII w. W okolicach Mukaczewa nie mówi się już o kneziostwie, ale o sołtystwie (scultetia).

98 O kopanicach jako elemencie krajobrazu kulturalnego zob. K. Pavličková, Analýza rozvoja myjavských kopaníc na základe vývoja využitia zeme, „Acta Enviromentalica Universitatis Comenianae” 2007, t. 15, z. 2, s. 83-93. 
W utrzymaniu młyna, dostarczać okrycia itd. ${ }^{99}$ Oddawano quinquagesimę z owiec i świń (Schaf- und Schweinemaut) burmistrzowi Sybina oraz świnie i sery miastu Szászsebes - Sebeş - Mühlbach, egzekwowano też dziesięcinę z jagniąt. Pastorowi saskiemu czy funduszowi jałmużniczemu dostarczano dziesięcinę ze zboża i wina, pobierano od nich też Medemabgaben za używanie pól i łąk oraz za używanie winnic. Wołosi mieli prawo wypasać owce na górskich halach należących do miast saskich, za co również uiszczali opłaty. Lasy mogły być karczowane na nowe łąki i hale tylko za zgodą miast. Wołosi mogli bezpłatnie brać drewno z lasów, ale tylko na własne potrzeby. Na budowę domów we wsiach konieczna była zgoda magistratów. Młyny traktowane były jako własność miasta, więc ich użytkowanie również obciążone było daniną, podobnie wyrób piwa i krojenie mięsa. Mieszkańcy pozbawieni też byli swego sądownictwa, należącego również do miasta, a także prawa wyboru urzędników ${ }^{100}$.

W powyższym przeglądzie powinności wołoskich uwagę zwraca duży udział obowiązków „wojskowych”. Wydaje się, że w początkowej fazie osadnictwa wołoskiego odgrywały one pierwszoplanową rolę i były czynnikiem warunkującym popieranie kolonizacji wołoskiej przez władców węgierskich, zgodnie z żywym w Monarchii Arpadów modelem osadnictwa obcoplemiennego rozwijającego się na terenach przygranicznych celem strzeżenia granic państwa ${ }^{101}$. Już Karel Kadlec zauważył, że pierwsze grupy wołoskie mogły być przyprowadzone w Góry Fogaraskie przez Bélę III w 1182 r. podczas jego walk na Bałkanach do obrony Węgier przed Kumanami ${ }^{102}$. W 1250 r. Béla IV potwierdził nadanie dokonane przez swego ojca Andrzeja II majątku Szolovna / Slanje w Chorwacji dla żupana sybińskiego Iwachina, syna Gechego, który associatis sibi Saxonibus, Olacis, Siculis et Bissenis wspomógł cara bułgarskiego Asena Boriła. Dokument wydany został dla synów Iwachina, Tomasza żupana Karakó oraz Filipa, biskupa zagrzebskiego. Cała akcja miała miejsce zdaniem Jánosa Karácsonyego w 1210 r., co byłoby najstarszym świadectwem wołoskiej obecności w węgierskiej strefie wpływów ${ }^{103}$.

Kolejną wzmiankę o Wołochach w kontekście wojennym przynosi list króla czeskiego Przemysła Otokara II do papieża Aleksandra IV, w którym monarcha donosił o swoim zwycięstwie nad wojskami króla Béli IV 12 lipca 1260 r. pod Kressenbrunn. Wymienił skład wojsk swoich przeciwników, wśród których obok Rusinów i Tatarów,

${ }^{99}$ Za: K. Kadlec, Valaši, s. 278.

100 K. Kadlec, Valaši, s. 279-280.

101 P. Engel, The Realm of St Stephen. A History of Medieval Hungary, 895-1526, transl. by T. Pálosfalvi, ed. by A. Ayton, London - New York 2001, s. 73-74.

102 K. Kadlec, Valaši, s. 170-171. Por. też ibidem, s. 212 nn. (o okręgach wołoskich na południowej granicy w XV w.), 226 nn. (o Marmaroszu jako okręgu granicznym przeciw Rusi i Tatarom).

103 Documenta, nr 10, s. 22-24; K. Kadlec, Valaši, s. 171; P. Engel, Magyarország világi archontológiája (płyta CD): Türje nem Szentgróti; A. Zsoldos, Magyarország világi archontológiája, s. 312. Filip później został arcybiskupem ostrzyhomskim. 
qui eidem in auxilium venerant et Boleslaum Cracoviensem et Lestkonem iuvenem, Lasiciae duces, et innumerammultitudineminhumanorum hominum Comanorumet Ungarorumetdiversorum Sclavorum, Siculorum nie zabrakło quoque et Walachorum, Bezzerminorum et Hysmahelitarum, scismaticorum etiam, utpote Graecorum, Bulgarorum, Rusciensium et Bosniensium haereticorum ${ }^{104}$.

Następna wzmianka o Wołochach dotyczy buntu wojewody Lythona i jego brata Barbatha. W jego thumieniu brał udział magister Jerzy, syn Szymona z rodu Baksa, który w nagrodę otrzymał posiadłości w Szaryszu, w tym Sóvár, dzisiejszy Solivar, dzielnica Preszowa. Ów Jerzy jest postacią znaną również z polskiej historii, bo w 1285 r., czyli roku wystawienia omawianego dokumentu, wspomagał on Leszka Czarnego, walczącego z buntem rycerstwa w Krakowie, a po paru latach wspomógł on jego młodszego przyrodniego brata Władysława Łokietka w jego walkach o tron krakowski ${ }^{105}$.

Wołochom powierzano ochronę granic ${ }^{106}$, np. w 1426 r. Zygmunt Luksemburski wyraził życzenie: Volumus, quod sicut hactenus sunt consueti, ita et in futurum dicti kenezius et villani de saepe dicta Bereckfalva ad faciendam custodiam in illis confinibus et ad explorationem in partibus Moldaviae obligati sint et adstricti ${ }^{107}$. O powinnościach strażniczych Wołochów orawskich czy północno trenczyńskich wspomnieliśmy wyżej ${ }^{108}$.

Jak już wspomniano wyżej, w 1294 r. Wołosi wsparli zbuntowanego wojewodę siedmiogrodzkiego Rolanda ${ }^{109}$. Nie dziwi też, że tak bojowo nastawiony lud stawał się sprawcą rabunków, o których stale słyszymy w źródłach. Już w 1315 r. Karol Robert rozstrzygnął spór o posiadłość Brythonia vocatam in comitatu de Hatzak existentem, que [--] per Dan et Ztonislaw kenezios esset occupata potentialiter et iniu-

\footnotetext{
104 Tekst został przekazany in extenso w spisanych Dziejach króla Przemysła Otokara II. Pokračowatelé Kosmowi. VI. Př́běhy krále Přemysla Otakara II., [w:] Fontes rerum Bohemicarum, t. 2. Cosmae Chronicon cum continuatoribus. Prameny dĕjin českých, výdavané z nadání Palackého, díl 2. Kosmův Letopis český s pokračovateli, wyd. J. Emler V. V. Tomek, Praha 1874, s. 315-316; Documenta, nr 13, s. 26. Warto zauważyć, że tytulatura młodego księcia Leszka (Czarnego) dobrze została oddana w przekładzie czeskim (Lenčickému), natomiast wydawcy Documenta określają go w ekscerpcie: „Leszko le jeune, prince de Lausitz”. P. Żmudzki, Studium podzielonego Królestwa. Książę Leszek Czarny, Warszawa 2000, s. 123-124, przy czym z niewiadomych przyczyn zapis Siculorum czyta jako Sirulorum i tylko w przyp. 19 domyśla się, że „Sirulowie to zapewne siedmiogrodzcy Szekelerzy [! - R. G.]”.

105 Documenta, nr 16, s. 30 - dokument z 8 stycznia 1285 r. O Jerzym zob. J. Dąbrowski, Z czasów Łokietka. Studia nad stosunkami polsko-wegierskimi w XIV wieku, cz. 1, Rozprawy Akademii Umiejętności, Wydział Historyczno-Filozoficzny, t. 59, 1916, s. 284; P. Engel, Magyarország világi archontológiája (książka), t. 2, s. 18 (ród Baksa); idem, płyta CD, Baksa rokonsága, tabl. 1. Jerzy był wiernym stronnikiem Władysława IV uczestniczącym w thumieniu powstania Rolanda, M. Homza, Politické dejiny Spiša do začiatku 14. storočia, [w:] Historia Scepusii, t. 1, s. 170, przodkiem rodziny sóvári Sós, gdyż dostał nadanie Sóváru (Solivaru), dzisiejszej dzielnicy Preszowa, dawnego Castrum Salis, gdzie jego potomkowie odnotowani byli jeszcze w XVI w. Był m.in. żupanem Szabolcsa, A. Zsoldos, Magyarország világi archontológiája, s. 305.

106 L. Wyrostek, Ród, s. 6.

107 K. Kadlec, Valaši, s. 211

108 Ibidem, s. 13.

109 Ibidem, s. 105.
} 
$s^{110}$. W 1343 r. przed podżupanem komitatu Krassó pojawił się Benedykt, syn Pawła (z rodu Himfy) i oświadczył, że Bracan Kenezius de Sosd cum Gregorio et Finta suis filiis ukradli 97 owiec jego ludziom z Remete ${ }^{111}$. Natomiast 20 stycznia 1357 r. przed konwentem w Kolozsmonostor pojawił się żupan Bálványos Péter Székely i zeznał, że w piątek przed Bożym Narodzeniem, czyli 23 grudnia 1356 r. Kulhon woyvoda ville Welpreth, Surban kenezius ... Demetrius, Christianus et Iwan Olachy in cetum maleficorum et numerum positi ad villam Zumbathtelke manibus armatis et potentiarii ... auctoritate ... venissent, mille ducentes oves jobagionum de ... et propulissent. Natomiast w piątek po oktawie Bożego Narodzenia napadli na wieś królewską Kutke, należącą do zamku Bálványos quinque boves et unum equum potentialiter modo premissi ... Dowiadujemy się też o zabiciu jednego konia ${ }^{112}$. W $1471 \mathrm{r}$. zbójcy wołoscy napadli na poselstwo wspólnoty saskiej wracające z Budy od króla Macieja Korwina i zabrali mu wieziony przywilej królewski nadający wspólnocie dochody z Fogaraszu ${ }^{113}$. Zaś w 1493 r. w szaryskim Bardejowie osądzono bandę Fedora Hlawatego, z którą współpracował ksiądz prawosławny z Krasnego Brodu w Zemplinie ${ }^{114}$.

Nie zawsze spory były wynikiem działań Wołochów. Znany nam już przypadek z Koromli ${ }^{115}$ powstał w wyniku działań żupana użhorodzkiego Wilhelma Drugeta, którego kasztelan osiedlił Wołochów na ziemiach należących do michałowickiej gałęzi rodu Kaplyon. Ale w 1413 r. wolahi z majątku Drugetów w Humennem wraz z Wołochami Benedykta Cudara napadli na majątek tibawski w komitacie uskim i skradli z niego 442 owce ${ }^{116}$. Dwanaście lat wcześniej doszło do osadzenia przez ród Baksa Sós Wołochów we wsi Kokošovce w Szaryszu, należącej do rodu Delnei, stąd skarga tych ostatnich ${ }^{117}$.

Nic też dziwnego, że sąsiedztwo Wołochów bywało ciężkie dla ich sąsiadów, szczególnie w XV i XVI w., gdy wzrosła gęstość zaludnienia. Już w pierwszych wiekach pobytu w Siedmiogrodzie dochodziło do konfliktów wołoskich pasterzy z osiadłą ludnością węgierską i saską ${ }^{118}$. Z późniejszych wieków wspomnijmy tylko skargi mieszkańców miast bańskich, że Wołosi pustoszą ich lasy, których drewno służyło do celów przemysłowych, i ustawiczne zakazy niszczenia lasów wydawane bezskutecznie przez Habsburskich cesarzy ${ }^{119}$.

110 Documenta, nr 31, s. 50-53.

111 Documenta, nr 69, s. 103-104.

112 Documenta, nr 96, s. 132-133 - dokument uszkodzony, opuszczenia w edycji.

113 K. Kadlec, Valaši, s. 99.

114 F. Uličný, Dejiny osídlenia Zemplínskej župy, s. 249-250 i 704.

115 Ibidem, s. 105.

116 J. Beňko, Osídlenie, s. 266; o Benedykcie, dworzaninie królewskim P. Engel, Magyarország világi archontológiája (książka), s. 46, płyta CD, Cudar (bőcsi, ónodi), tabl. 2. Cudar.

117 F. Uličný, Dejiny osídlenia Šariša, s. 206.

118 K. Kadlec, Valaši, s. 177.

${ }^{119}$ V. Chaloupecký, Valaši, s. 47-48. Dla przykładu zapis komisarzy cesarskich z komory w Wiedniu (ibidem, przyp. 90, s. 47-48) z 1540 r.: Unsere räte und commisarien (sollen) mit allen vleisz darob sein, damit die Walachen, welche mit iren vieh halten die weld wast vereden, von unsern grundten hinwegekh 
Z wojskowymi zajęciami wiąże się też ewolucja położenia kneziów i wojewodów wołoskich, widoczna szczególnie w Siedmiogrodzie. Jak już wyżej wspomniano, kneziowie pełnili zasadniczo funkcję zasadźców, analogicznie do sołtysów prawa niemieckiego. Byli też przywódcami grupy krewniaczej, a później lokalnej ${ }^{120}$. Obok nich w źródłach pojawili się też wojewodowie. Po raz pierwszy spotykamy się z tą funkcją w $1247 \mathrm{r}$. w znanym nam już dokumencie nadania ziemi joannitom przez Bélę IV ${ }^{121}$. Pojawia się tam wojewoda Lytuoy - Litvoj oraz Szeneslaus. Litvoj był zarazem kneziem ziem nad Alutą, zaś Szeneslaus (spolszczając imię to możnaby oddać jako Senesław ${ }^{122}$ ) wojewodą ziem na wschód od Aluty, w stronę Kumanii. Wyżej przytoczono też dokument z 1285 r., w którym wspomina się o buncie Lython woyuoda ${ }^{123}$. Przypuszcza się, że mógł on być tożsamy z Litvoyem z 1247 r. Wojewoda wykorzystał chaos panujący wówczas na Węgrzech po śmierci Stefana V i prawdopodobnie w 1273 r. odmówił uiszczania trybutu. Bunt został stłumiony, Litvoy chyba stracił życie, a jego brat Barbath został wówczas uwięziony ${ }^{124}$. Od XIV w. wojewodowie pojawiają się w źródłach w szeregu komitatów objętych kolonizacją wołoską. Jak zauważa Karel Kadlec, ich znaczenie zmienia się w czasie i przestrzeni. Początkowo wydaje się, że zgodnie z etymologią słowiańskiej nazwy urzędu byli przywódcami wojskowymi, odpowiadali też za ściąganie podatków. Nie jest jasny ich stosunek do kneziów, ale wydaje się, że byli nadrzędni wobec nich i obejmowali władzą teren kilku kenezatów ${ }^{125}$. Później ich rola została zredukowana do roli urzędników właściciela majątku, w którym osiedli Wołosi, jak w jednym z nielicznych znanych przypadków występowania urzędu wojewody w Zemplinie ${ }^{126}$.

getan werden. Na kolejnych stronach pracy dalsze przykłady niszczenia lasów przez Wołochów, np. s. 54 przyp. 109: ... non solum a Walachis ... magnam devastationem esse factam exstirpatis multis in locis silvis, verum etiam agros et prata eos ibidem confecisse. Już w 1384 r. mieszkańcy miast górniczych w Górach Rodniańskich skutecznie interweniowali u królowej Marii w sprawie zakazu wyrębu drewna na węgiel w nigra silva regalis, nałożonego na nich przez wojewodę wołoskiego Balka z rodu DragówSasów. L. Wyrobek, Ród, s. 20. Por. też O. Tomeček, Valasi, s. 33.

120 Ibidem, s. 109, przyp. 72 i 73.

121 Ibidem, s. 104, przyp. 34. Analiza L. Rădvan, At Europe's Borders. Medieval Towns in the Romanian Principalities, transl. by V. Cîrdei, Leiden-Boston 2010, s. 121-125.

122 Jednak imienia tego nie odnotował Stownik staropolskich nazw osobowych, red. W. Taszycki, t. 5 , Wrocław-Warszawa-Kraków 1977-1980. K. Kadlec, Valaši, s. 447 imię to rekonstruuje jako Stanisław. Takiej formy nie odnotowuje wspomniany Stownik, ib., s. v. Stanisław, s. 179-182.

123 Ibidem, s. 116, przyp. 105.

${ }^{124}$ L. Makkai, Magyar-román, s. 31; C. C. Giurescu, Istoria Românilor, t. 1: Din cele mai vechi timpuri până la moartea lui Alexandru cel Bun (1432), wyd. D. C. Giurescu, Bucureşti 2000, s. 288-289; V. Rădvan, At Europe's Border, s. 128-129.

${ }^{125}$ V. Rădvan, At Europe’s Border, s. 124. K. Kadlec, Valaši, s. 250 zakładał równość kneziów i wojewodów z wyjątkiem Marmaroszu, gdzie widoczna była przewaga wojewodów.

${ }^{126}$ K. Kadlec, Valaši, s. 234 nn. Tam analiza wojewodów w poszczególnych komitatach siedmiogrodzkich i północno-wschodnio węgierskich. F. Uličný, Dejiny osídlenia Zemplínskej župy, s. 705 uznaje, że wojewodom podlegało 10-20 wsi wołoskich. Ibidem, s. 398 stwierdzenie, że wojewodowie byli urzędnikami właścicieli wsi Pichne z rodu Drugetów, gdzie w 1413 r. pojawiają się Stephanus et Sthan vaivode. Por. też s. 701, przyp. 88. J. Beňko, Osídlenie, s. 266 podkreśla, że wojewoda miał władzę sądowniczą nad wszystkimi Wołochami osiadłymi w majątku Humenné, do którego należała wieś. 
Podobną ewolucję przeszedł urząd krajnika, mianowanego przez władcę czy później właściciela spośród kneziów czy wojewodów naczelnika okręgu zwanego Krainą ${ }^{127}$. Początkowo była to instytucja państwowa, rodzaj marchii pogranicznej powołanej do strzeżenia terenów przygranicznych, zaś w w późniejszym okresie ta organizacja terytorialna uległa „prywatyzacji” i funkcjonowała w ramach majątków, np. „państwa” stropkowskiego w Zemplinie w połowie XVI w. Krajnicy obok funkcji namiestników tych okręgów mieli też funkcje sądowe nad kneziami i wojewodami, podczas gdy kneziowie, przypomnijmy, sądzili zwykłych Wołochów ${ }^{128}$.

Szczególne znaczenie miał urząd wojewody w Marmaroszu. Był to teren geograficznie izolowany, leżący w górnym biegu Cisy. Wojewodowie byli tu wybierani przez wszystkich Wołochów, co potwierdza w 1364 r. królowa Elżbieta biorąca w obronę wojewodów wołoskich w Beregu, którzy mają być wybierani tak, jak w sąsiednim Marmaroszu przez ogół Wołochów ${ }^{129}$. Mimo obieralności wykształciła się tu silna władza tych urzędników, dysponujących prywatnymi majątkami, władzą i ambicjami. Marmaroska Kraina stała się punktem wyjścia dla niejakiego Dragosza do przekroczenia łańcucha Karpat i osiedlenia się po ich wschodniej stronie, gdzie w imieniu Ludwika Wielkiego zaczął tworzyć struktury administracyjne, nową Krainę chroniącą Węgry od Tatarów. Stało się to chyba w 1359 r., choć niektórzy badacze przesuwają ten czas do 1352 r. Kilka lat później, ok. 1363-64 r. przeciwko królowi zbuntował się inny wojewoda marmaroski Bogdan, krewny wojewody Basaraba, rządzącego już wtedy samodzielnie Wołoszczyzną (Havaselve). Bogdan przeszedł za Karpaty i pokonał syna Dragosza Sasa zakładając nowe państwo, Mołdawię. Sas wrócił do Marmaroszu i jako rekompensatę otrzymał od króla wszystkie majątki Bogdana, które jego potomkowie, zwani po węgiersku Drágfi, posiadali aż do początku XV w., kiedy w wyniku buntu przeciwko Zygmuntowi Luksemburskiemu utracili posiadłości marmaroskie, a wierny monarsze członek rodu otrzymał Béltek w komitacie szatmarskim, który stał się dalszą siedzibą węgierskiej gałęzi rodu ${ }^{130}$.

127 Nazwę tę spotykamy w różnych częściach Słowiańszczyzny na oznaczenie ziemi pogranicznej, Zob. odpowiednie hasła w Stowniku starożytności słowiańskich, t. 2, Wrocław-Warszawa-Kraków 1964: F. Sławski, W. Kowalenko, W. Sobociński, Kraina (Carniola), s. 501-503; T. Wasilewski, Krajište Kraj-Krajina, s. 503-504 (dotyczy Bałkan); P. Szafran, Krajna, s. 504 (dotyczy krainy nad Notecią).

128 K. Kadlec, Valaši, s. 239-247; F. Uličný, Dejiny osídlenia Zemplínskej župy, s. 705.

129 Documenta, nr 139, s. 177; L. Wyrostek, Ród, s. 13 i przyp. 2; V. Chaloupecký, Valaši, s. 21.

130 K. Kadlec, Valaši, s. 179-181 (działalność Bogdana), 250-252 (bunt i losy obu rodów); L. Wyrostek, Ród, s. 1-19. W dalszym ciągu autor przekonująco wywodzi wołoską genezę (od jednego z synów Sasa, Stefana, który znika ze źródeł węgierskich, a pojawia się w polskich) polskiego rodu Dragów-Sasów; L. Rădvan, At Europe’s Borders, s. 320-322; P. Engel, Magyarország világi archontológiája (płyta CD): Drágfi (bélteki). 


\section{STRUKTURA SPOŁECZNA WOŁOCHÓW}

Los wojewodów marmaroskich pokazuje nam jeszcze jedno ważne zjawisko społeczne, które zachodziło co najmniej od początku XIV w. Chodzi o zróżnicowanie struktury społecznej tego ludu. Pojawienie się kniaziów i wojewodów sugeruje, że już w najwcześniejszym okresie pobytu Wołochów na Węgrzech wśród nich istniała elita władzy, która jest niezbędna w każdej społeczności. Pod koniec XIII w. stali się na tyle silnym elementem w Siedmiogrodzie, że wzięli udział w zgromadzeniu universis nobilibus, Saxonibus, Syculis et Olachis z królem Andrzejem III odbytym apud Albam Iule w marcu 1291 r. ${ }^{131}$ Zaś po trzydziestu pięciu latach, w 1326 r. pewien kneź Stanisław, syn Stana otrzymał od króla Karola Roberta nadanie ziemskie wraz z pełnym immunitetem more et lege nobilium. Był to pierwszy kneź podniesiony do stanu szlacheckiego, od niego zdaniem wydawców Dokumentów do historii Wołochów na Węgrzech miały wywodzić się węgierskie rody Barcán oraz Hodor ${ }^{132}$. Wspomnieliśmy już pokrótce o marmaroskich początkach rodu Drágfi z Bélteku, który w XV w. należał do warstwy rządzącej na Węgrzech ${ }^{133}$. Z sąsiedniego Beregu pochodził Karachun (Karácson), który uzyskał majątek Bilke (dziś Biłky). Stał się on przodkiem rodów Bilkei, Lipcei oraz Gorzón ${ }^{134}$. Chyba największą karierę spośród rodów wołoskich zrobili potomkowie bojara pochodzącego z Wołoszczyzny (Havaselve) Serbana. Jego syn Vajk został w 1409 r. dworzaninem królewskim i w tymże roku otrzymał majętność w komitacie Hunyad. Od nazwy komitatu ród przybrał określenie Hunyadi (= z Hunyadu). Jego syn János był w połowie XV w. najpotężniejszym człowiekiem na Węgrzech zarządzającym praktycznie tym krajem i skutecznie broniącym go przed Turkami (np. zwycięsko przetrwał oblężenie Belgradu). Zaś jego młodszemu synowi Maciejowi szlachta węgierska ofiarowała koronę nie spodziewając się chyba, że na tron wstąpi jeden z najwybitniejszych władców tego kraju w historii, którego sławę opromienią nie tylko zwycięskie wojny, ale i zainteresowanie kulturą, zwłaszcza zgromadzenie słynnej biblioteki znanej od jego przydomka jako Corviniana ${ }^{135}$.

131 Documenta, nr 19, s. 32-36.

132 Documenta, nr 40, s. 66-70 i przyp. 1 do s. 67. Rodów tych nie uwzględnia P. Engel, Magyarország világi archontológiája (płyta CD, książka).

133 Miklós Drágfi był np. palatynem węgierskim w latach 1439-1444, zaś jego syn Bertalan był zausznikiem Macieja Korwina, a po jego śmierci Władysława Jagiellończyka. L. Wyrostek, Ród, s. 22; P. Engel, Magyarország világi archontológiája (płyta CD), Drágfi (bélteki); książka, t. 2, s. 65. Komitaty, w których ród ten miał swe włości, wylicza L. Makkai, Magyar-román, s. 67. m

134 Documenta, nr 52, s. 81-83 i przyp. 2 do s. 81 (dokument rozgraniczenia majętności dokonany przez kapitułę egerską na polecenie króla 30 stycznia 1339 r.). Już dwa lata później konwent w Lelesu skarżył się na szkody wyrządzone przez Karacsona sługom klasztornym de Chet (Csetfalva na dzisiejszej granicy ukraińsko-węgierskiej, ukr. Czetfalwa, Четфальва). Dоситеnta, nr 56, s. 85-86 i nr 57, s. 87. P. Engel, Magyarország világi archontológiája, t. 2, s. 37; brak na płycie CD.

135 L. Makkai, Magyar-román, s. 67; P. Engel, Magyarország világi archontológiája (książka), t. 1, s. 330, 498, t. 2, s. 103-104; płyta CD: Hunyadi (Corvin). O Bibliotece zob. np. Cs. Csapodi, K. Csapodi-Gárdonyi, Bibliotheca Corviniana. The Library of King Matthias Corvinus of Hungary, Budapest 1981 
Kariery wołoskiej szlachty pokazują, że szybko stapiała się ona z Natio Hungarica, tworząc jednolity węgierski stan szlachecki. Wiązało się to jednak z madziaryzacją i przechodzeniem na katolicyzm. Pozostali kneziowie, wojewodowie i Olachi populani ${ }^{136}$ nie osiągnęli wyżyn stanu szlacheckiego i traktowani byli jako ludność poddańcza, której położenie, jak widzieliśmy wyżej, systematycznie się pogarszało. Karel Kadlec zauważa, „že knezové králem potvrzení nerovnali se všeobecně šlechticům, nýbrž že jen jejich soudní výpoved' měla váhu výpovědi šlechticovy"137. Nic też dziwnego, że gdy w Siedmiogrodzie wybuchło wielkie powstanie chłopów i drobnej szlachty, kierowane przez Antala Nagya z Budy i w obliczu zagrożenia zawarto 16 września $1437 \mathrm{r}$. braterską unię trzech narodów Siedmiogrodu (unio trium nationum), wśród jej sygnatariuszy nie znaleźli się Wołosi, traktowani jako poddani. Stało się to źródłem postępującego ich wykluczenia, a od XVII w. włączenie do niej postulatem kształtującej się inteligencji rumuńskiej ${ }^{138}$. Widzieliśmy też, że osadnictwo wołoskie stopniowo zrównywało się pod względem obciążeń z osadnictwem niemieckim, a ludność w czasach nowożytnych zaliczana była do kategorii ludności poddańczej.

\section{STOSUNKI WYZNANIOWE}

Do niższego statusu społecznego Wołochów na Węgrzech bez wątpienia obok charakteru zajęć, dominujących zwłaszcza w pierwszym okresie istnienia, przyczyniała się wyznawana przez nich wiara. W liście z 14 listopada 1234 r. papież Grzegorz IX pisał do Béli IV, że na terytorium biskupstwa kumańskiego ${ }^{139}$ znajdują się quidam populi, qui Walati vocantur. Mimo, iż określają się jako chrześcijanie, mają obrzędy inne, niż prawdziwe chrześcijaństwo i

(wcześniejsze wyd. 1967, 1969). Mimo rozproszenia po świecie niekiedy udaje się zebrać zachowane książki na wystawach, np. w grudniu 2018 r. w Bibliotece Széchényich w Budapeszcie. Wołochem i członkiem Natio Hungarica był też Nicolaus Olahus (Miklós Oláh, 1493-1568), prymas Węgier, dyplomata, autor dwóch traktatów Hungaria (1536) i Athila (1537). Por. M. D. Birnbaum, Attila's Renaissance in the Fifteenth and Sixteenth Centuries, [w:] Attila. The Man and His Image, ed. by F. H. Bäuml and M. D. Birnbaum, Budapest 1993, s. 86-90.

136 Documenta, nr 112, s. 146. Jest to dokument z 2 czerwca 1360 r., w którym wicewojewoda i żupan Hátszegu poinformował wojewodę siedmiogrodzkiego o przeprowadzonym w najbliższą środę po Zielonych Świątkach zgromadzeniu ogólnym (congregationem generalem) Wołochów, w którym de medio ipsorum viros idoneos et fidedignos videlicet de Keneziis duodecim, ex sacerdotibus sex et similiter sex ex Olachys populanis infradeclaratos pro iuratis assessoribus nobis deputari fecissemus.

137 K. Kadlec, Valaši, s. 206.

138 Była to unia narodu węgierskiego, szlachty szeklerskiej i mieszczan saskich. K. Kadlec, Valaši, s. 285; W. Felczak, Historia Węgier, wyd. 2 popr. i rozsz., Wrocław-Warszawa-Kraków 1983, s. 81; Kurze Geschichte, s. 222. Zob. wyżej, s. 8.

139 Chodziło o biskupstwo milkowskie powołane dla nawracania Kumanów podległe arcybiskupstwu ostrzyhomskiemu. Kurze Geschichte, s. 188. 
a quibusdam pseudoepiscopis Grecorum ritum tenentibus uniuersa recipiunt ecclesiastica sacramenta et nonnulli de regno Ungarie tam Ungari quam Theutonici et alii orthodoxi morandi causa cum ipsis transeunt ad eosdem et sic cum eis quia populus unus facti cum eisdem Walathis eo contempto premissa recipiunt sacramenta.

Należy zatem dla tych Walati powołać sufragana, który przywróciłby ich Kościołowi rzymskiemu ${ }^{140}$. W 1256 r. król Béla IV zezwolił arcybiskupowi ostrzyhomskiemu na udział w dziesięcinie zbieranej w posiadłościach królewskich ex parte Siculorum et Olacorum in pecudibus, pecoribus et animalibus quibuslibet, exceptis terragiis Saxonum, sed ex parte Olacorum etiam ubique et a quocumque provenientium, in regno Hungarie persolvi consuetorum ${ }^{141}$. W 1328 r. papież Jan XXII wzywał prałatów węgierskich do łagodności w egzekwowaniu dziesięcin od niedawno nawróconych Cumanis, Alachis [sic] et Sclavis, by nie odepchnąc ich od Kościoła ${ }^{142}$. W liście z 17 października 1345 r. papież Klemens VI wspomina, że Olachi Romani commorantes in partibus Ungarie, Transsilvanis, Ultraalpinis et Sirmiis przeszli na katolicyzm albo to obiecali uczynić1 ${ }^{143} .22$ lipca 1366 r. papież Urban V ponownie naciskał, by „heretycy” na Węgrzech przyjęli wiarę katolicką, a już dwa dni wcześniej król Ludwik zarządzil, by omnes Sclavos sacerdotes apud vos existentes cum eorum pueris, uxoribus et rebus omnibus absque omni dampno, lesione et deturpatione duci facere debeatis magistro Benedicto. Sprawa dotyczyła komitatów Keve i Krassó, czyli południowych kresów Królestwa ${ }^{144}$. Autorzy kodeksu dyplomatycznego ilustrującego historię Wołochów na Węgrzech zwracają uwagę, że to zarządzenie króla stanowiło wyłom $\mathrm{w}$ dotychczasowej praktyce monarchów węgierskich i wiązało się z interwencją w Bułgarii na rzecz cesarza bizantyńskiego Jana V, który uznał zwierzchność papieża. Walka przeciw Bułgarom przybrała więc cechy krucjaty. Skończyło się to wkrótce po zawarciu pokoju w 1368 r. A wcześniej spotykamy się np. z decyzją biskupa waradyńskiego Dymitra dotyczącą jego wsi Felwenter, ut unum presbiterum Olachalem, donec nostre placuerit voluntati, sine omni collecta et exactione qualibet nobis iure domini provenire debentibus possit et valeat conservare. Jest to swoją drogą pierwsza wzmianka o księdzu wołoskim we wsi ${ }^{145}$. W znanym już nam dokumencie o zjeździe wołoskim odbytym w Hátszegu 2 czerwca 1360 r. u boku wicewojewody siedmiogrodzkiego sprawy rozpatrywali m.in. Petrus archydiaconus de Oztro, Zampa de Clapatiua, Balk de Possana, Dalk de Domsus et Dragomyr de Tusta ecclesiarum sacerdotes Olachales ${ }^{146}$. W 1368 r. Myrizlow sacerdos bierze z braćmi Dragusem, Stefanem i Dragomerem udział w podziale dóbr Gyulaháza oraz Nyres

140 Documenta, nr 7, s. 17-19.

141 Documenta, nr 12, s. 25-26 i nr 14, s. 27.

142 Documenta, $\mathrm{nr} 41$, s. 70.

143 Documenta, $\mathrm{nr} 73$, s. 106-107.

144 Documenta, nr 153, s. 201, por. przyp. 2 do tej strony, s. 201-203 oraz B. Varsik, Osídlenie, t. 3, s. 376 .

145 Documenta, nr 81, s. 114 z 17 lipca 1349. Na s. 202 błędnie: 1345.

${ }^{146}$ Documenta, nr 112, s. 147, por. ibidem, s. 202. 
po swoim ojcu Gyuli Valachusie ${ }^{147} .13$ sierpnia 1390 r. patriarcha Konstantynopola

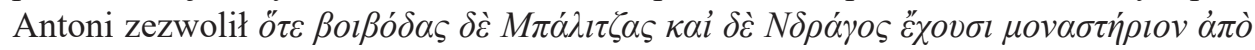

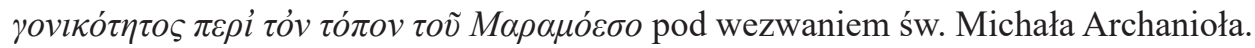
Fundacji dokonano w Körtvélyes, dzisiejszym Hruszowie na Ukrainie. Dokument został zatwierdzony przez Władysława Jagiellończyka w 1494 r. pod warunkiem, że klasztor nie będzie już podlegać patriarsze, lecz biskupowi mukaczewskiemu ${ }^{148}$.

A jednak wciąż trwały próby przyciągnięcia Wołochów do wiary katolickiej. Chyba pierwszym odnotowanym przykładem konwersji jest przypadek Şorbana z Ócsvy w komitacie csanádzkim. Król Ludwik 16 maja 1366 r. zaświadczył, że

fidelis noster Olachus Sorban vocatus de Ochwa, quem in ritum katholico baptizatum Stephanum fecimus appellari otrzymał $\mathrm{w}$ dziedziczne władanie quandam possessionem nostram regalem Kisachwicha vocatam prenominate possessioni Ochwa contigue vicinantem cum omnibus eius utilitatibus, fructibus et pertinentiis ${ }^{149}$.

\section{W 1374 r. papież Grzegorz XI w liście do króla Ludwika zauważył, że}

certa pars multitudinis nationis Wlachorum qui circa metas regni tui versus Tartaros commorantes secundum ritus et scisma Grecorum vivebant, prout longe maior pars eorum adhuc vivit została nawrócona na katolicyzm, zaś alii de ipsis Wlachonibus, cum sint homines simplices et convertibiles, ad fidem veritatis satis faciliter converterentur cum assistentia tui favoris, si de proprio antistite per apostolicam sedem provideretur eisdem cum de solo ministerio sacerdotum Ungarorum non bene contentari dicantur.

Zdaniem wydawców Dokumentów chodzi tu o tereny mołdawskie ${ }^{150}$. Treść tę papież powtórzył w liście napisanym tego samego dnia 13 października 1374 r. do obu węgierskich arcybiskupów. Dodał on, że planuje powołać biskupa misyjnego dla tego ludu, franciszkanina Antoniego de Spalato, qui linguam dicte nationis asseritur et qui tempore dicte conversionis multos ex dictis Valachis convertisse, baptizasse ${ }^{151}$. Jednak do nominacji wyraźnie nie doszło, a przechodzenie elit wołoskich na katolicyzm $^{152}$ spowodowało, że prawosławie stało się religią ludności wołoskiej z niż-

147 Documenta, nr 170, s. 215-216.

148 Documenta, nr 371, s. 418-421: omówienie francuskie z fragmentami po grecku, a następnie to samo z fragmentami tłumaczenia łacińskiego dokonanego w 1494 r. Tekst łaciński zob. L. Wyrostek, Ród, s. 17 przyp. 2. Dokument datowany jest na 13 sierpnia 6899 r. ery bizantyńskiej, co wydawcy dokumentów rozwiązują jako sierpień 1391, zaś Ludwik Wyrostek jako „około r. 1390”. Zgodnie z zasadami ery bizantyńskiej, w której rok zaczynał się 1 września, a era chrześcijańska w roku 5508, należy datę rozwiązać jako 13 sierpnia 1390 r. Zasady obliczania zob. H. Wąsowicz, Chronologia średniowieczna, Lublin 2013, s. 222-223.

149 Documenta, nr 148, s. 189-190.

150 Documenta, nr 211, s. 254; B. Varsik, Osidlenie, s. 376.

151 Documenta, nr 212, s. 255.

152 L. Wyrostek, Ród, s. 26: „Odnośnie do spraw kościelnych i wyznaniowych można przypuścić, że od chwili przejścia do Beltek [Drágfiowie] należeli do Kościoła katolickiego. Bartłomiej i Jan położyli duże zasługi przez fundacje kościołów w obrębie dóbr rodowych. Jan szczycił się przyjaźnią papieża i braterskim przywiązaniem biskupa Siedmiogrodu, Franciszka Wardy, który obdarował go hojnie 
szych warstw społecznych. W XV w. widzimy, że księża prawosławni należą do niższej warstwy społecznej ${ }^{153}$. Przywołaliśmy już przykład „bat'ki” z Zemplina, który był członkiem bandy rozbójników ${ }^{154}$. Inny przykład podaje Ján Beňko, który zauważył, że Jerzy Rákoczi w 1624 r. oswobodził ,popa” z szaryskich Kečkoviec od powinności z wyjątkiem rocznej opłaty w wysokości 10 florenów i oddania skóry kuny. W tym czasie księża katoliccy zwolnieni byli od wszelkich danin i cieszyli się jeszcze przywilejami ${ }^{155}$. Hieronim Łaski w 1539 r. w Hodemarku, dzisiejszym Stotincu na Spiszu osiedlił Ruthenos, Walachos et schismaticos ${ }^{156}$. Matej (Mátyás) Bel (Bél) pisał w połowie XVIII w. o Sarmatach na Spiszu, zwanych Rutenami, którzy służbę Bożą odbywali według rytu greckiego ${ }^{157}$. W $1646 \mathrm{r}$. w Użhorodzie doszło do zawarcia unii kościelnej między biskupem egerskim a 63 kapłanami prawosławnymi. Duchowni za uznanie władzy papieskiej mieli otrzymać równy status z duchowieństwem rzymskokatolickim, ale ta obietnica nigdy nie została dotrzymana ${ }^{158}$. W 1700 r. doszło do unii w Alba Iulii obejmującej mieszkańców Siedmiogrodu i księstw rumuńskich, która jednak nie zlikwidowała Kościoła prawosławnego na tych terenach ${ }^{159}$.

\section{STOSUNKI ETNICZNE}

Wróćmy do niedoszłego biskupa misyjnego dla Wołochów, franciszkanina Antoniego de Spalato. Branislav Varsik mylnie zinterpretował nazwę miejsca pochodzenia zakonnika wysnuwając z tego wniosek, že totiž Anton ze Spoleta pochádzajúci z talianského prostredia poznal ich [czyli Wołochów - R. G.] reč, ktorá mohla byt' len rumunská $a^{160}$. Tymczasem chodzi nie o włoskie Spoleto, lecz dalmatyńskie Spalato, czyli Split. Oczywiście było to środowisko romańskie, ale silnie już wtedy przemieszane

i uczynił wykonawcą swej woli ostatniej. Kasper zboczył z tej linii, lecz wkrótce poszedł śladami przodków”. Zboczył, bo „był pierwszym z pośród magnatów wschodnio-węgierskich, który przyczynił się do rozkrzewienia protestantyzmu, tak w obrębie własnych dóbr, jak również w podległych mu komitatach". Ibidem, s. 24.

153 P. Kónya a kol., Dejiny Uhorska, Prešov 2013, s. 371 (autorem jest P. Kónya): „Ortodoxná cirkev mala zasadne odlišné postavenie, než katolicka. Jej duchovní neboli súčastou kňazského stavu a mali postavenie poddanych, pričom boli povinní odvádzat' svojim zemepánom aj osobitné dávky”. Por. też K. Kadlec, Valaši, s. 286-287.

154 Ibidem, przyp. 117.

155 J. Beňko, Osídlenie, s. 236; F. Uličný, Dejiny osídlenia Šariša, s. 129-130; idem, Dejiny osidlenia Užskej župy, s. 311-312.

156 J. Beńko, Osídlenie, s. 175.

157 H. Ruciński, Hospodárske štruktúry, s. 386.

158 F. Uličný, Dejiny osídlenia Zemplinskej župy, s. 704; Dejiny Uhorska, s. 373; V. Olejník, Dejiny Spišského prepoštstva v rokoch 1526-1776, [w:] Historia Scepusii. Dejiny Spiša, red. M. Homza, S. A. Sroka, t. 2, Bratislava - Kraków 2016, s. 643-644.

${ }^{159}$ Dejiny Uhorska, s. 373.

160 B. Varsik, Osídlenie, t. 3, s. 376. 
ze słowiańskim. Można zakładać, że Antoni był co najmniej dwujęzyczny, romańsko-słowiański. I taki właśnie charakter Wołochów jawi się nam w najstarszych źródłach węgierskich. Nikt nie wątpi w ich romańskość, na to wskazuje samo ich określenie będące egzonimem, a zatem nazwą nadaną im przez sąsiadów. Nazwa ta w ustach Słowian oznaczała ludy romańskie, neo-łacińskie, a ich pozostałością jest określenie Italii mianem Włoch, a jej mieszkańców nazwą Włosi ${ }^{161}$. Oni sami od początku chyba określali się jako Rumân. Ale wiele imion zapisanych w dokumentach, które przytaczane były w niniejszym eseju, nosi piętno słowiańskie. Senesław, Stanisław, Bogdan, Dan to tylko pierwsze z brzegu przykłady. Nazwy funkcji: kenez czyli kniaź, wojewoda, organizacja terytorialna kraina z krajnikiem, wszystkie one są czysto słowiańskie i trudno przypuszczać za László Makkaiem, by były one wyłącznie produktem recepcji węgierskiego systemu feudalnego ${ }^{162}$. Należy postawić hipotezę, że Wołosi napływający do Siedmiogrodu od końca XII w. byli ludem o heteroetnicznej strukturze, romańsko-słowiańskim. Mimo romańskich korzeni i być może tradycji związków z Rzymem przechowywanej w nazwie etnicznej ${ }^{163}$ ich słowiańskość wzmacniała liturgia, która wbrew korzeniom tego ludu sprawowana była w języku starocerkiewnosłowiańskim. Język ten pozostawał zresztą językiem przekazu kulturalnego w księstwach rumuńskich do XVII w. Ale w ciągu swej długiej historii i ekspansji osadniczej struktura etniczna Wołochów ulegała zmianie. Oto w dokumencie wystawionym 25 października 1385 r. nakazuje się universis iobagionis nostris in Regen existentibus et aliis iobagionibus nostris tam Olachys quam Oroz in partibus Transilvanis existentibus, by udzielili pożyczki Jánosowi Veresowi ${ }^{164}$. Pokazuje to, że w Siedmiogrodzie obok Wołochów przebywali również Rusini. Idąca od południa kolonizacja wołoska zmieszała się z idącym z terenów ruskich na Zakarpacie wschodnio-słowiańskim prądem osadniczym ${ }^{165}$. Silny element słowiański składający się na kolonizację wołoską w Siedmiogrodzie ułatwił asymilację Wołochów do Rusinów, tak więc już w Marmaroszu termin Wołoch pod koniec XIV w. zaczął tracić swoje pierwotne znaczenie przesuwając się w stronę określenia pasterza, osadnika na prawie wołoskim. Pod pojęciem Wołochów coraz częściej rozumiano Rusinów ${ }^{166}$. Wydaje się, że rację ma Branislav Varsik, który w źródłach z końca XIV w. dostrzegł proces mieszania się obu nacji - osobno wymieniani są Wołosi, osobno Rusini ${ }^{167}$. Ci ostatni tworzyli odrębną falę osadniczą przekraczającą główny grzbiet Karpat i zasiedla-

161 Kwestie genezy i ewolucji nazwy są przedstawione w innych częściach niniejszej monografii.

162 Kurze Geschichte, s. 193-194.

163 Pytanie, jak określać w języku polskim w odniesieniu do średniowiecza lud będący przedmiotem niniejszego studium rozstrzygnął definitywnie Olgierd Górka na IV Powszechnym Zjeździe Historyków Polskich w Poznaniu w 1925 r.: „,wniosek co do zastąpienia terminu „Wołoch” słowem „Rumun” jest możliwy wyłącznie w odniesieniu do historii nowszej. Średnie wieki znają tylko ludność wołoską, prawo wołoskie i szereg innych określeń, które wiążą się jedynie z pojęciem „Wołoch, wołoski” (sery, sukna, konie itd.)". Cytat za: L. Wyrostek, Ród, s. 5 przyp. 2.

164 Documenta, nr 294, s. 322.

165 I. Szabó, Ugocsa megye, s. 122.

166 Documenta, s. 343 przyp. 3 i s. 344 przyp. 3.

167 B. Varsik, Osídlenie, t. 3, s. 377-378. Por. wyżej przyp. 157. 
jącą istniejące już wsie prawa niemieckiego, np. w 1337 r. we wsi Vinné w komitacie uskim odnotowano, że winnica należała do Ozyph Rutheni hospitis de eadem Vynna ${ }^{168}$. $\mathrm{Z}$ biegiem czasu osiedlano ich na prawie wołoskim. Można zgodzić się z tymi badaczami, którzy sądzą, że etnos rumuński w osadnictwie wołoskim w Królestwie Węgierskim został wyparty przez etnos ruski na początku XV w. na dzisiejszym pograniczu rumuńsko-ukraińskim względnie ukraińsko-słowackim ${ }^{169}$. Prawdopodobnie istnieje koincydencja między wyparciem elementu romańskiego a zanikiem typowej dla wcześniejszej, siedmiogrodzkiej fazy kolonizacji nazwy dla przywódcy osadników, knezia, ktory od źródeł zemplińskich na zachód jest określany jako sołtys (rychtar $)^{170}$. Zasięg osadnictwa ruskiego sięgał Spisza, leżąca na Zamagurzu pod Tatrami Bielskimi Osturnia jest dzisiaj najbardziej na zachód wysuniętą wsią z zachowaną kulturą ruską ${ }^{171}$. Kolonizacja terenów położonych bardziej na zachód pod względem etnicznym odbywała się już z przewagą miejscowego elementu słowackiego oraz polskich przybyszów z północnej strony Karpat ${ }^{172}$.

\section{PODSUMOWANIE}

Podsumowując powyższe uwagi musimy zauważyć, że kolonizacja wołoska na Węgrzech była długotrwałym prądem osadniczym, który można podzielić na kilka faz. Pierwszą z nich była faza pasterstwa koczowniczego w XIII w. w Karpatach Południowych. Niewykluczone jednak, że już wtedy Wołosi zaczęli osiedlać się w stałych osadach, jak w Doboce w 1219 r. Coraz powszechniej czytamy o wołoskich osadach w Fogaraszu, banacie Krassó-Szörény (Caras-Severin), potem w górach zachodniego Siedmiogrodu po najeździe tatarskim, kiedy wyludniona ziemia czekała na nowych gospodarzy. Prowadzono tam chyba już transhumacyjny wypas owiec polegający na wyprowadzaniu owiec na półroczny redyk w góry latem i powrót do niżej położonych osad zimą prowadzony przez wyspecjalizowanych pasterzy, podczas gdy reszta społeczności pozostawała w osadzie zajmując się innymi czynnościami

168 B. Varsik, Osídlenie, t. 3, s. 370; F. Uličný, Dejiny osídlenia Užskej župy, s. 267-272 (bez wzmianki o Rusinach). O osadnikach ruskich na prawie niemieckim pisze M. Wołoszczuk: М. Волощук, „Русь” в Угорському Королівстві (XI- друга половина XIV cm.). Суспільно-політича роль, майнові стосунки, митраиіï, Івано-Франківськ 2014, passim, zwł. s. 140-141 (Гості, Hospes, Hospites) oraz 199-200.

169 Tu por. V. Chaloupecký, Valaši, s. 20: „Proto také jeví se nám, že nositeli valašské kolonisace na rozhraní krajů rumunských a ukrajinských byli Rumuni, dale však na rozhraní krajů rusínských a slovenských opět Rusíni, na západĕ pak při východní hranici Moravy a Slovenska, popřidadĕ Slezska, nabývá valašská kolonisace s hlediska ethnického povahy slovenské”. Zob. też prace rumuńsko-bułgarsko-czechosłowackiego uczonego Dimitra Krandžalova (D. Crănjală), np. Valaši na Moravě. Materiály, problemy, metody, Praha 1963.

170 Ibidem, s. 109.

171 A. Patek, Demografický vývoj na Spiši, [w:] Historia Scepusii, t. 2, s. 492.

172 J. Beňko, Osídlenie, s. 79; O. Tomeček, Valasi, s.32. Ale V. Chaloupecký, Valaši, s. 84-85 dopuszcza znaczny udział Rusinów w kolonizacji Orawy. 
(rzemiosło, serowarstwo). Wtedy też zaczyna się polityczna rola Wołochów, czytelna choćby w buncie wojewody Litvoja. Pod koniec XIII w. spotykamy Wołochów praktycznie w całym Siedmiogrodzie, ich reprezentanci dopuszczeni są do decydowania o regionalnej polityce, o czym świadczy udział przedstawicieli wołoskich w zebraniu stanów siedmiogrodzkich z królem Andrzejem III.

Kolejną fazę kolonizacji wołoskiej wyznaczają pierwsze dziesięciolecia XIV w., kiedy do dużego znaczenia dochodzi wołoska kraina (czyli okręg administracyjny) w Marmaroszu. Pojawia się wołoska arystokracja. Przedstawiciele jednego z rodów tworzą „krainę” na wschód od Karpat, w Mołdawii, zarządzając nią w imieniu władców węgierskich, ale wyparci przez buntowników osiadają na powrót w Marmaroszu. W Mołdawii powstaje niezależne państwo, obok Wołoszczyzny leżącej na południe od Karpat Południowych jedno z dwóch państw rumuńskich, które zjednoczą się dopiero w XIX w. dając początek dzisiejszej Rumunii. Natomiast magnackie rody, zarówno marmaroskie, jak i pochodzące z innych komitatów, zaczęły wtapiać się w Natio Hungarica, stając się częścią elity władzy i kultury na Węgrzech, ale przyjmując też węgierską tradycję i katolicyzm. Oznaczało to utratę przez ogół Wołochów elit i obniżenie prestiżu społecznego ogółu ludności, ktora odtąd zaliczana była do ludności poddańczej.

Wiek XIV to równiez dalsza ekspansja osadnicza wzdłuż łuku karpackiego, która objęła Beskid Niski, a na przełomie XIV i XV w. doszła do Spisza oraz na Nizinę Nadcisańską. Wtedy rozpoczęła się zmiana składu etnicznego. W romańsko-słowiańskich społecznościach osadniczych coraz większą przewagę zdobywał żywioł wschodnio-słowiański - rusiński. Od początków XV w. kolonizacja wołoska nosi jednoznaczny, ruski charakter.

Wiek XV to dalszy postęp osadnictwa, który objął bardziej na zachód położone partie Beskidów i pasma fatrzańskie, jak i góry środkowej Słowacji (Kras Spisko-Gemerski, dolinę Hronu) dochodząc na przełomie XV i XVI w. aż do północnych części komitatu trenczyńskiego i Kysuc (Czadeckiego). Stamtąd kolonizacja przechodziła na Morawy i na Śląsk Cieszyński. Jest to już wyłącznie nowa fala osadnicza zajmująca trudniej dostępne i dotąd nieużytkowane gospodarczo tereny dogodne zwłaszcza do wypasu zwierząt.

Wiek XVI i XVII to kontynuacja osadnictwa. Jak się wydaje, z biegiem czasu doszło do urolnienia gospodarki. Pojawiły się typowe dla współczesnego krajobrazu beskidzkiego porozrzucane po stokach górskich przysiółki, których mieszkańcy usiłowali uprawiać ubogą glebę. W źródłach stosuje się terminologię typową dla osadnictwa niemieckiego, a o wołoskim charakterze świadczą jedynie daniny, jakie zobowiązana była złożyć ludność właścicielom oraz (od połowy XVI w.) państwu.

Najbardziej typową daniną była quinquagesima z owiec, niekiedy też ze świń, która z biegiem czasu na dzisiejszej Słowacji uległa zaostrzeniu na vigesimę. W przypadku pierwszej z danin ze stu owiec oddawano dwie, w przypadku drugiej pięć. Zwracają uwagę daniny w serach, skórach zwierzęcych i wyrobach z nich uzyskanych, ale również powinności strażnicze, czyli obowiązek ochrony dróg prowadzących przez góry, zwalczanie zbójectwa oraz służba na zamkach. Pokazuje to, że osadnictwo wołoskie obok gospodarczego miało też charakter militarny. 
Wołosi jako tajemniczy lud fascynowali od samego początku intelektualistów. Odnotował ich już Anonim węgierski. Szerzej przypatrywali się im humaniści włoscy, których uwagę zwróciło podobieństwo ich języka do łaciny i włoskiego. By je wyjaśnić, stworzyli teorię ich pochodzenia od rzymskich kolonistów osadzonych w Dacji przez cesarza Trajana. Pogląd ten, propagowany przez humanistów węgierskich, przejęty został przez siedmiogrodzkich przedstawicieli kształtującej się inteligencji rumuńskiej stając się po dziś dzień elementem rumuńskiej mitologii narodowej.

\section{BIBLIOGRAFIA}

\section{Źródła:}

A nagymihályi és sztáray gróf Sztáray család oklevéltára, wyd. Gy. Nagy, t. 1, Budapest 1887.

Aenae Sylvii Piccolominei ... opera quae extant omnia... His quoque accessit Gnomologia..., Basileae [1551], https://archive.org/details/ARes63312/page/n3 [dostęp: 23.10.2019].

Anonimowego Notariusza króla Béli Gesta Hungarorum, thum. A. Kulbicka, K. Pawłowski, G. Wodzinowska-Taklińska, wstęp i przypisy R. Grzesik, Kraków 2006.

Anonymi Descriptio Europae Orientalis „Imperium Constantinopolitanum, Albania, Serbia, Bulgaria, Ruthenia, Ungaria, Polonia, Bohemia” anno MCCCVIII exarata, ed. O. Górka, Cracoviae 1916.

Anonymus and Master Roger. Anonymi Bele regis notarii Gesta Hungarorum. Anonymus, Notary of King Béla, The Deeds of the Hungarians, ed., transl. and annotated by M. Rady and L. Veszprémy. I Magistri Rogerii Epistola in miserabile Carmen super destructione regni Hungarie per Tartaros facta. Master Roger's Epistle to the Sorrowful Lament upon the Destruction of the Kingdom of Hungary by the Tatars, transl. and annotated by J. M. Bak and M. Rady, Budapest-New York 2010.

Antonii Bonfinii Rervm Vngaricarvm Decades Qvatvor cvm dimidia, (...), ed. Ioannes Sambucus, Francofvrti, Apud Andream Wechelum 1581 Cum priuilegio decem annorum, https://books. google.hu/books?id=8sc9AAAAcAAJ\&printsec=frontcover\&hl=pl\#v=onepage\&q\&f=false[dostęp: 15.10.2019].

Bunyitay V., A váradi káptalan legrégibb statutumai, Nagyvárad 1886.

Chronica de gestis Hungarorum e Codice Picto saec. XIV. Chronicle of the Deeds of the Hungarians from the Fourteenth-Century Illuminated Codex, red. J. M. Bak, L. Veszprémy, wstęp N. Kersken, Budapest-New York 2018.

Chronici Hungarici compositio saeculi XIV., ed. A. Domanovszky, [w:] Scriptores rerum Hungaricarum, t. 1, Budapestini 1937, s. 217-505.

Codex diplomaticus Andegavensis, ed. I. Nagy, Gy. Tasnády Nagy, t. 1-7, Budapest 1878-1920.

Documenta Historiam Valachorum in Hungaria illustrantia usque ad annum 1400 p. Christum, curante Emerico Lukinich, prof. ord. Universitatis Budapestinensis et adiuvante Ladislao Gáldi ediderunt Antonius Fekete Nagy et Ladislaus Makkai, Budapestini 1941, https://library.hungaricana.hu/hu/ view/KozMagyOkmanytarak_documenta_historiam_1941/?pg=8\&layout=s [dostęp: 26.01.2020].

Gagyi J., Az árvavármegyei oláh telepek kiváltságlevele, „Történelmi Tár” 1910, s. 186-198.

Heltai Gáspár, Krónika az magyaroknak dolgairól, wyd. M. Kulcsár, wstęp P. Kulcsár, Békéscsaba 1981. Johannes de Thurocz, Chronica Hungarorum, pars 1: Textus, ed. E. Galántai et J. Kristó, Budapest 1985. Opis jeograficzny i statystyczny Węgier, Siedmiogrodu, Kroacyi i Pogranicza Wojskowego, Warszawa 1849. P. magistri, qui Anonymus dicitur, Gesta Hungarorum, ed. Ae. Jakubovich, D. Pais, [w:] Scriptores rerum Hungaricarum, t. 1, Budapestini 1937, s. 13-117.

Pii secundi pontificis maximi Commentarii rervm memorabilivm, quae temporibus svis contingervnt, a Reverendissimo Domine Ioanne Gobellino Vicario Bonnensi iamdiu composite et a Reverendissimo 
Patre Domine Francisco Bandino Picolomineo Archiepiscopo Senensi ex vetusto originali recogniti ... Prostat Francofurti in Officina Avbriana Anno 1614, https://books.google.pl/books?redir_esc=y\& $\mathrm{hl}=\mathrm{pl} \& \mathrm{id}=\mathrm{CJQVBq} 5 \times 6 \mathrm{AQC} \& \mathrm{q}=$ Valachi\#v=snippet\&q=Valachi\&f=false [dostęp: 23.10 .2019 ].

Pokračowatelé Kosmowi. VI. Příběhy krále Přemysla Otakara II., [w:] Fontes rerum Bohemicarum, t. 2. Cosmae Chronicon cum continuatoribus. Prameny dějin českých, výdavané z nadání Palackého, díl

2. Kosmův Letopis český s pokračovateli, wyd. J. Emler V. V. Tomek, Praha 1874, s. 308-335.

Povest'vremennyh let, č. 1: Tekst i perevod, wyd. D. S. Lihačev, V. P. Adrianovaya-Peretc, MoskvaLeningrad 1950 [Повесть временных лет, ч. 1: Текст и перевод, wyd. Д. С. Лихачев, В. П. Адриановая-Перетц, Москва-Ленинград 1950].

Regestrum Varadinense examinum ferri candentis ordine chronologico digestum descripta effigie editionis a. 1550 illustratum sumptibusque Capituli Varadinensis Lat. Rit. curis et laboribus Joannis Karácsonyi et Samuelis Borovszky Academiae Scientiarum Hungaricae membrorum editum, Budapest 1903.

Ritvs explorandae veritatis, qvo Hvngarica natio in dirimendis controuersijs ante annos trecentos \& quadraginta vsa est, \& eius testimonia plurima, in Sacrario summi temple Varadiensi reperta, Colosuarij 1550.

Simonis de Kéza Gesta Hungarorum. Simon of Kéza, The Deeds of the Hungarians, With a study by J. Szúcs, wyd. L. Veszprémy i M. Rady, Budapest 1999.

Słownik łaciny średniowiecznej w Polsce, red. M. Plezia, t. 1: A-B, Wrocław-Warszawa-Kraków 19531958.

Słownik łaciny średniowiecznej w Polsce, t. 7, z. 1 (52), Kraków 1992.

Testimoniach najdawniejszych dziejów Słowian, seria łacińska, t. 3: Średniowiecze, z. 1: Źródła węgierskie, w opracowaniu.

Verancsics Antal, M. Kir. helytartó, esztergomi érsek, Összes munkái, közli Szalay László, M. Akad. T., első kötet: Történelmi dolgozatok deák nyelen, Pest 1857.

\section{Opracowania:}

Beňko J., Osídlenie severného Slovenska, Košice 1985.

Birnbaum M. D., Attila's Renaissance in the Fifteenth and Sixteenth Centuries, [w:] Attila. The Man and His Image, ed. by F. H. Bäuml and M. D. Birnbaum, Budapest 1993, s. 82-96.

Bogdán I., Metrológia, [w:] A történelem segédtudományai, red. I. Bertényi, Budapest 1998, s. 331-350.

Chaloupecký V., Valaši na Slovensku, Praha 1947.

Cojocaru T., Valasi na Slovensku a v Pol’sku. Predbežné úvahy, [w:] Valašská kolonizácia na Slovensku a slovenská kolonizácia v Rumunsku. Zborník príspevkov z 10. zasadnutia Komisie historikov Slovenska a Rumunska (Banská Bystrica, 25.-27. september 2012), Banská Bystrica 2014, s. 20-26 (i streszczenie angielskie: Vlachs in Slovakia and Poland. Some preliminary considerations, s. 26).

Czuczor G., Fogarasi J., A magyar nyelv szótára, Pest 1862, https://mek.oszk.hu/05800/05887/ pdf/1kotet_2.pdf [dostęp: 01.02.2020].

Csapodi Cs., Csapodi-Gárdonyi K., Bibliotheca Corviniana. The Library of King Matthias Corvinus of Hungary, Budapest 1981.

Dąbrowski J., Z czasów Łokietka. Studia nad stosunkami polsko-węgierskimi w XIV wieku, cz. 1, Rozprawy Akademii Umiejętności, Wydział Historyczno-Filozoficzny, t. 59, 1916.

Deletant D., Ethnos and Mythos in the History of Transylvania: the case of the chronicler Anonymus, [w:] Historians and the History of Transylvania, ed. by L. Péter, New York 1992, s. 67-85.

Du-Nay A., A román nép kialakulása s korai története, Bp. 2004.

Engel P., Magyarország világi archontológiája 1301-1457, Budapest 1996.

Engel P., Magyarország világi archontológiája 1301-1457. Középkori magyar genealógia, Arcanum Digitéka. Magyar Középkori Adattár, Budapest 2001 (płyta CD).

Engel P., The Realm of St Stephen. A History of Medieval Hungary, 895-1526, transl. by T. Pálosfalvi, ed. by A. Ayton, London-New York 2001.

Felczak W., Historia Wegier, wyd. 2 popr. i rozsz., Wrocław-Warszawa-Kraków 1983. 
Gamillscheg E., Blachii ac pastores Romanorum, [w:] Omagiu lui Ioan Lupaş la împlinirea vîrstei de 60 de ani, Bucureşti 1943, s. 270-276.

Giurescu C. C., Istoria Românilor, t. 1: Din cele mai vechi timpuri până la moartea lui Alexandru cel Bun (1432), wyd. D. C. Giurescu, Bucureşti 2000.

Grzesik R., Blasi and Pastores Romanorum in the Gesta Hungarorum by an Anonymous Notary, „Res Historica" 2016, t. 41, s. 25-34.

Grzesik R., Great Moravia as the Basis of the Central European Medieval Historical Tradition, [w:] Slovensko a Chorvátsko. Historické paralely a vztahy (do roku 1780). Slovaćka i Hrvatska. Povijesne paralele i veze (do godine 1780.), red. M. Homza, J. Lukačka, N. Budak, Bratislava 2013, s. 66-71.

Grzesik R., Kronika węgiersko-polska. Z dziejów polsko-węgierskich kontaktów kulturalnych w średniowieczu, Poznań 1999.

Grzesik R., The Valachian Way of Life in Stories about Domestic Origins in the Hungarian Medieval Chronicles, „Balcanica Posnaniensia” 2016, t. 23, s. 167-174.

Györffy Gy., Adatok a románok XIII. századi történetéhez és a román állam kezdeteihez, cz. 1, „Történelmi Szemle" 1964, R. 7, z. 1, nr 24, s. 1-25.

Györffy Gy., Az Árpád-kori Magyarország történeti földrajza, t. 2, Budapest 1987.

Hardi Đ., Drugeti. Povest o usponu i padu porodice pratilaca Anžujskih kraljeva, Novi Sad 2012.

Historia Scepusii. Dejiny Spiša, red. M. Homza, S. A. Sroka, t. 1, Bratislava-Kraków 2009.

Historia Scepusii. Dejiny Spiša, red. M. Homza, S. A. Sroka, t. 2, Bratislava-Kraków 2016.

Hóman B., A Szent László-kori Gesta Ungarorum és a XII-XIII. századi leszármázói, Budapest 1925, rozdz. 6: A Szent László-kori Gesta és Anonymus, http://mek.niif.hu/07100/07139/html/0008/0008338.html [dostęp: 22.10.2019].

Homza M. a kol., Svätopluk v európskom písomnictve. Štúdie z dejín svätoplukovskej legendy, Bratislava 2013.

Kadlec K., Valaši a valašské právo v zemích slovanských a uherských, s úvodem podávajicím přehled theorií o vzniku rumunského národa, Praha 1916.

Kętrzyński W., O powołaniu Krzyżaków przez księcia Konrada, Rozprawy Akademii Umiejętności, Wydział Historyczno-Filozoficzny, t. 45, 1903, s. 130-145.

Kiss L., Földrajzi nevek etimológiai szótára, t. 1: A-K, Budapest 1997.

Klein G., Péchy-Horváth R., Mezökeresztes, [w:] Borsod vármegye (Borsod, Gömör és Kishont K. e. e. vármegyek), red. A. Csíkvári, Budapest 1939 (Vármegyei szociográfiák, t. 5), IV rész: Községi adattár, s. 89-90.

Kónya P. a kol., Dejiny Uhorska, Prešov 2013.

Krandžalov D., Valaši na Moravě. Materiály, problémy, metody, Praha 1963.

Kristó Gy., Rómaiak és vlachok Nyesztornál és Anonymusnál, [w:] Idem., Tanulmányok az Árpád-korról, Bp. 1983, s. 132-190.

Kurze Geschichte Siebenbürgens, red. B. Köpeczi, Budapest 1990.

Leśny J., Konstantyn i Metody apostołowie Stowian. Dzieło i jego losy, Poznań 1987.

Madgearu A., The Romanians in the Anonymous Gesta Hungarorum. Truth and Fiction, Cluj-Napoca 2005.

Madgearu A., Vlach Military Units in the Byzantine Army, [w:] Samoilovata država i Vizantija: istorija, legenda, tradicija, nasledstvo. Zbornik na trudovi od Meǵunarodniot simpozium „Denovi na Justinian I“", Skopje, 17-18 oktomvri 2014, red. M. B. Panov, Skopje 2015, s. 47-55 [Самоиловата држава и Византија: историја, легенда, традиција, наследство. Зборник на трудови од Меѓународниот симпозиум „Денови на Јустиниан I“, Скопје, 17-18 октомври 2014, red.

М. Б. Панов, Скопје 2015, s. 47-55].

Maisel W., Archeologia prawna Europy, Warszawa-Poznań 1989.

Makkai L., Magyar-román közös múlt, wyd. 2, bmw. 1989.

Maliniak P., Čabradské panstvo v stredoveku, Banská Bystrica 2019.

Miskolczy A., Románok a történeti Magyarországon, Budapest 2005.

Niederhauser E., A történetírás története Kelet-Európában, Budapest 1995. 
Nowak J., Piastuni dziejów. Wizerunki narodów europejskich w polskiej refleksji romantycznej, Warszawa 2018, https://ispan.waw.pl/ireteslaw/bitstream/handle/20.500.12528/603/J_Nowak_-_Piastuni_dziejow.pdf?sequence=1\&isAllowed=y [dostęp: 18.02.2020].

Pavličková K., Analýza rozvoja myjavských kopaníc na základe vývoja využitia zeme, ,Acta Enviromentalica Universitatis Comenianae" 2007, t. 15, z. 2, s. 83-93.

Rácz A., A régi Bihar vármegye településneveinek történeti-etimológiai szótára, Debrecen 2007.

Rădvan L., At Europe's Borders. Medieval Towns in the Romanian Principalities, transl. by V. Cîrdei, Leiden-Boston 2010.

Sławski F., Kowalenko W., Sobociński W., Kraina (Carniola), [w:] Stownik starożytności słowiańskich, t. 2, Wrocław-Warszawa-Kraków 1964, s. 501-503.

Stownik staropolskich nazw osobowych, red. W. Taszycki, t. 5, Wrocław-Warszawa-Kraków 19771980.

Szabó I., Ugocsa megye, Budapest 1937.

Szafran P., Krajna, [w:] Słownik starożytności słowiańskich, t. 2, Wrocław-Warszawa-Kraków 1964, s. 504.

Tamás L., Rómaiak, románok és oláhok Dácia Trajánában, Budapest 1935.

Tomeček O., Valasi na území Zvolenskej stolice, [w:] Valašská kolonizácia na Slovensku a slovenská kolonizácia v Rumunsku. Zborník príspevkov z 10. zasadnutia Komisie historikov Slovenska a Rumunska (Banská Bystrica, 25.-27. september 2012), Banská Bystrica 2014, s. 27-39.

Uličný F., Dejiny osidlenia Šariša, [Košice] 1990.

Uličný F., Dejiny osídlenia užskej župy, Prešov 1995.

Uličný F., Dejiny osidlenia Zemplínskej župy, Michalovce 2001.

Varsik B., Osidlenie Košickej Kotliny, t. 3, Bratislava 1977.

Voloŝuk M., ,,Rus '” v Ugors 'komu Korolivstvi (XI-druga polovina XIV st.). Suspil'no-politična rol', majnovi stosunki, migraciï, Ivano-Frankivs'k 2014 [Волощук М., „Русь” в Угорському Королівстві (XI - друга половина XIV cm.). Суспільно-політича роль, майнові стосунки, митрачї, Івано-Франківськ 2014].

Wasilewski T., Krajište - Kraj - Krajina, [w:] Stownik starożytności słowiańskich, t. 2, WrocławWarszawa-Kraków 1964, s. 503-504.

Wąsowicz H., Chronologia średniowieczna, Lublin 2013.

Wyrostek L., Ród Dragów-Sasów na Węgrzech i Rusi Halickiej, Kraków 1932.

Żmudzki P., Studium podzielonego Królestwa. Książę Leszek Czarny, Warszawa 2000.

Zsoldos A., Magyarország világi archontológiája 1000-1301, Budapest 2011. 